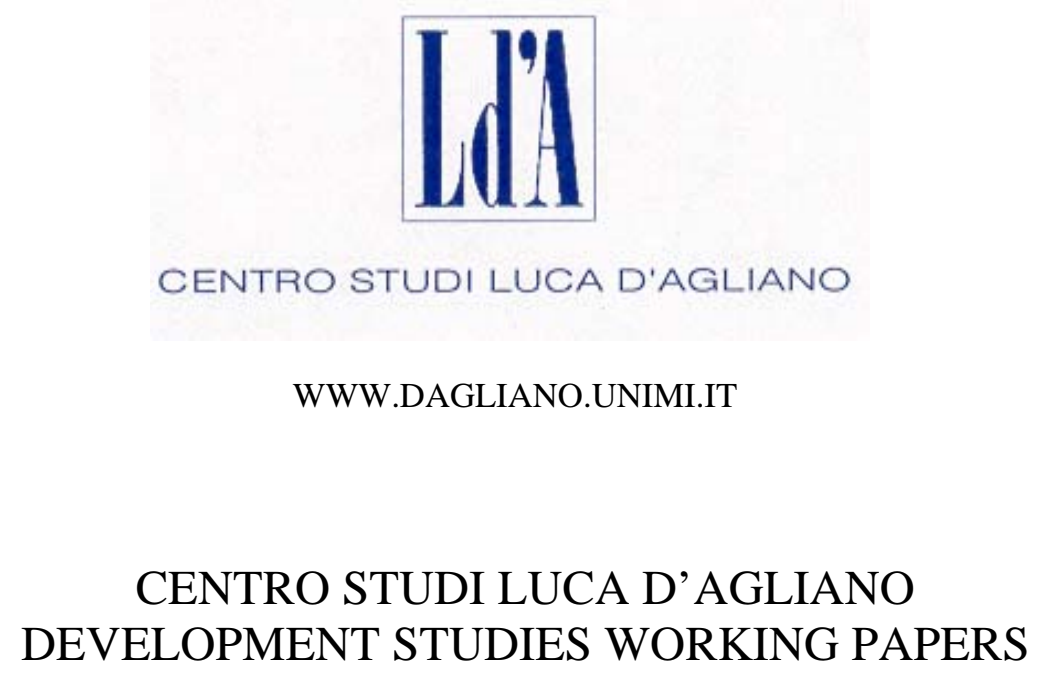

N. 265

October 2008

\title{
Migration Enclaves, Schooling Choices and Social Mobility
}

Mario Piacentini*

* University of Geneva 


\title{
Migration Enclaves, Schooling Choices and Social Mobility
}

\author{
Mario Piacentini*(University of Geneva)
}

October 22, 2008

\begin{abstract}
This paper investigates the presence of a network externality which might explain the persistence of low schooling achievements among internal migrants. We test empirically whether young migrants' schooling decisions are affected by the presence of covillagers at destination, using data on life-time histories of migration and education choices from a rural region of Thailand. Different modelling approaches are used to account for the self-selection of young migrants, for potential endogeneity of the network size, and for unobserved heterogeneity in individual preferences. The size of the migrant network is found to negatively affect the propensity of young migrants to pursue schooling while in the city. This finding suggests that policies seeking to minimise stratification in enclaves might have a socially multiplied impact on schooling participation, and, ultimately, affect the socio-economic mobility of the rural born.
\end{abstract}

Keywords: education, networks, migration

JEL No: I21,L14,O15

${ }^{*}$ I am grateful to Jaime de Melo for valuable advice. An earlier version was co-awarded the first prize at the 7th. GEP conference at the University of Nottingham. Thanks for helpful comments from participants at the GEP conference, at the graduate seminar of the department of economics at the University of Geneva, at the Young Swiss Economist Meetings of 2008, from Richard Upward and from Nicola Coniglio and participants at the "Migration and Development Conference", University of Lille I am also thankful to Eik Leong Swee for sharing his rain data and programs. All remaining errors are mine. Corresponding address: Department of Economics, Uni Mail, Bd du Pont d'Arve 40, 1211 Genève 4, Switzerland. E-mail: mario.piacentini@ecopo.unige.ch 


\section{Introduction}

"People in the city and people in the village aren't the same. City people, Bangkok people, you can't trust them, they only think of themselves. In the city people don't know each other. I've lived in this room for many months now and I still don't know the neighbors. In the village I know everyone. We grow up together, we're all relatives and friends together. I know where they come from, their background. I can trust them." Daeng, a 20-year-old textile operative quoted in Mills (1997)

Disparities in growth between urban and rural areas, as well as reduction in migration costs, act as powerful pull factors augmenting the demographic pressures on overcrowded cities of developing countries. It is tempting to assert that the access to more remunerative employment opportunities in urban agglomerates increases the expected returns on education and therefore acts as an incentive to invest in human capital for those planning to migrate. However, young migrants take the decision to pursue schooling beyond a literacy level jointly with their family and are influenced by the broader social network they belong to. It is increasingly recognized that differences in the composition and exclusion mechanisms of these networks affect opportunity costs of higher education.

Economic research on network effects and welfare of the migrant population has produced contrasting results. One strand of the literature emphasizes that the reliance of migrants on origin-specific social capital can be associated with a lower rate of assimilation of destinationspecific skills. Among others, Borjas (1995) has shown that ethnic neighborhoods have detrimental effects on the educational attainment of migrants in the US. A competing hypothesis is that ethnic or origin-based concentration of migrants is a source of opportunities for gainful interactions in the labor market, for example by disseminating information on job opportunities. Banerjee (1983)'s research on rural-urban migration in India documents extensively the importance of networks of covillagers for explaining migration flows, success of initial job search, and duration of urban employment. With evidence in support of both positive and negative effects, it is unclear how segmentation along enclaves affects economic performance of migrants.

This paper tests the hypothesis that migrant networks might act as important externalities in the education process of young migrants, representing a potential determinant of the observed low educational attainments. The empirical analysis is inspired by the theoretical literature on group inequality, which argues that a family living in a disadvantaged community can optimally decide to invest relatively less in schooling when network externalities are in place (Bowles \& Sethi (2006)). The literature identifies two network externality mechanisms through which segregation in enclaves can emerge endogenously that are relevant for this paper and are reviewed below. The first draws on Benabou (1996)'s research on stratification in the urban space, leading 
migrants to concentrate in neighborhoods less favorable to human capital investments. The second argues that migrant families care about being accepted among members of their own origin community, and that they might be willing to reduce their investments in human capital to avoid the costs of exclusion.

I test the relevance of this network externality using unique data from Thailand, the Nang Rong Project database. This dataset provides direct individual and family information on both migrants and stayers, through longitudinal surveys in the villages and migrant follow-ups in the main urban destinations. It also includes rich retrospective information on migration and education decisions that allows me to work with a panel data set of individual location decisions and schooling outcomes, from multiple communities and to multiple destinations, over a long period of time. In contrast to the majority of contributions in the migration literature, I can take advantage of this balanced representation of migrants and stayers to control for the fact that those choosing to migrate and to join the migrant network at destination are not a random sample of the rural young population.

I examine the role of networks on the schooling decision of young internal migrants, as higher education is believed to be an important proxy for social mobility of migrants within the urban labor market ${ }^{1}$. The young migrant's network is measured by the number of sampled individuals from his village who are located at his destination at each point in time. Identification of network effects is based on the fact that each village has a different history of migration so that the rural young coming from different villages rely on networks of contacts that are developed differently ${ }^{2}$. The potential endogeneity of the network effect is controlled through instrumental variable estimation extending the approach in Munshi (2003) to include the aggregation of networks at the tiny village level. The network size variable is instrumented by the exogenous source of variation associated with random, ballot-based, assignment of young to the military service. The forced movement to the cities of the rural young men balloted to serve in the military tends in fact to be accompanied by increased voluntary migration of these same young and others villagers in later years. Additional instruments for network size are a proxy for exposure of rice cultivators to rain variability, and a lagged measure of the incidence of return migration to the village.

The estimates show that a larger network of co-villagers at destination lowers the probability that a young migrant is enrolled in higher schooling. I interpret this result as an indication that social interactions with the "origin" network matter in determining the migrant "long term"

\footnotetext{
${ }^{1}$ An increasing number of studies shows the importance of education for migrant assimilation and long-term earning prospects. Yamauchi (2003), examining wage dynamics of migrants in Bangkok, shows evidence of a complementarity between upon-arrival human capital and labor market experience at destination. His results imply that more-educated migrants have higher learning efficiency and can perform tasks of greater complexity, ultimately yielding higher wage growth in the destination market. In the context of international migration, some important contributions have shown that the source of human capital matters, the one acquired at destination being more rentable on the labor market (see Friedberg (2000) and Eckstein \& Weiss (1998))

${ }^{2}$ Thai villages were historically fairly tightly bounded social communities and traditional village life was relatively isolated, generating a common community culture and encouraging behavioral conformity (Godley (2001)). Of course, this static picture is evolving now with the increasing migration flows to the cities.
} 
profile, in terms of willingness to acquire destination-specific human capital and, possibly, in terms of the speed at which he is able to converge to natives' performances on the labor market. The robustness of the results is confirmed when I shift to an alternative multinomial mixed logit approach for the joint migration and education decisions, which accounts explicitly for individual heterogeneity.

These findings suggest that network effects can act as a driving mechanism of low-mobility traps among migrants. As a result, the important role networks play in facilitating migration and easing life at destination might come at a cost, slowing down the convergence of people of rural origin to the average level of skills of the urban born. Considering the strength of the links migrants keep with their origin villages (by remittances, return episodes and as role models), it cannot be excluded that this network effect on human capital might reinforce persistence in inequality between backward rural areas and dynamic urban poles in developing countries.

The remainder of the paper is organized as follows. Section 2 discusses the theoretical literature on group segregation and educational investment. Section 3 describes the data and the network measure used. Section 4 develops and reports on the econometric analysis. Section 5 concludes.

\section{Social networks and schooling in the theory of segregation}

\subsection{Network spillovers and human capital inequality between groups}

The implications of segregation for differential human capital accumulation and persistent inequality have been formalized by Bowles and Sethi (2006). In their model, the population is split by birth in two distinct groups. Individuals have a preference for association with individuals of their group, which is defined as segregation. Such diversity in social network composition translates into different opportunity costs of human capital accumulation, as an externality is in place linking each training achievement of a young with those of the other individuals to which he is tied. Indeed, an increasing number of contributions in sociology and in economics show that people coming from rural areas and urban born often constitute two very distinct groups who behave differently in the city environment (see Mills, 1997).

Assume then that there is a higher proportion of skilled among natives than among migrants coming to the city when internal migration starts gaining momentum, not a strong assumption if one recognizes that skills acquired at the rural village are not fully transferable at destination. Consistently with Bowles and Sethi (2006)'s framework, this initial inequality in the allocation of skills between migrants and non migrants can be shown to widen and persist in time if segregation is high enough. Persistent group inequality arises as a result of the social externality in the costs of education, with no need to assume discrimination in the labor market or binding liquidity constraints for education. These conclusions rule out one-shot redistributive policies as effective instruments for equalization although the scope for intervention improves if one is 
willing to drop the assumption of an exogenously fixed level of segregation.

\subsection{Why do networks externalities emerge? Residential enclaving and human capital accumulation}

One potential determinant of origin-biased social networking is the residential segmentation of groups in city space. Think of the utility maximization problem faced by the adult as involving also a location decision among two different neighborhoods, each parent trading off the benefit of a better environment for his child's learning with the cost of higher rents. Bénabou (1996) proves that location stratification is generated endogenously (those from one specific community preferring to locate in one specific neighborhood) as an equilibrium, if those rich in human capital are able to bid more than the poor for living in the community with a higher endowment of human capital. Formally, Bénabou's sorting condition says that the marginal rate of substitution between the network quality and the rent price increases with the parents' level of education. If this sorting condition holds, any divergence from the symmetric initial allocation of skill between groups, sets in motion a cumulative process with skilled (higher income) people outbidding unskilled (lower income) people for the privilege of locating close to other skilled people. When translated to the issue of internal migration, this simply means that the migrants, starting from a lower level of human capital, have on average less to bid in the trade-off between community quality and rents, and end-up disproportionately in neighborhoods less favorable to human capital investments. Segregation in the city space is a variable that can be affected by policy: differentiated taxes and subsidies can be effective in reallocating families across communities (Bénabou, 1996), and urban regeneration programs can raise the attractiveness of neighborhoods where there is an historically higher concentration of migrants ${ }^{3}$.

\subsection{Other Sources of network externalities: Social signalling and preference for conformity}

As spatial and social proximity are likely to be correlated, the allocation of individuals in stratified neighborhoods can alone generate segmentation. However, other mechanisms can explain why migrants can rationally prefer to maintain segregated social relations. Consider first a scenario in which a young person derives utility from being part of his origin group and admission to the group is selective. It seems reasonable to assume that migrants can diverge in the value they assign to group participation and that the migrant community might preserve its cohesion by excluding families signalling little interest in participation by "deviant" behaviors. One of these behaviors can be an investment in the schooling progression of the young which is

\footnotetext{
${ }^{3}$ This issue is acknowledged by policy makers. The housing projects of the National Housing Authority (NHA) and the Bangkok Metropolitan Administration (BMA) have engaged in ensuring some mix of housing at all price range in each area. In addition, the Bangkok Plan addresses existing spatial disparities in the location of jobs and housing, and encourages balanced jobs and housing growth in each of the city planning units (see Tapananont $(2004))$.
} 
believed excessive by the group. One reason, among others, is that the school enrollment of the young already able to work can make a migrant family temporarily unable to meet some social obligations, like sending to the village a minimal amount of remittances. When the social type is private knowledge then, conflicting incentives to invest in destination-specific human capital and to signal loyalty to the group can be a channel through which historical group differences in human capital levels spill over into the next generation's investment behavior ${ }^{4}$.

A related, but distinct, channel endogenously creating correlation between young and established migrants'schooling choices is the youngs' preference for conformity. The young can be assumed to bear an utility cost when failing to conform to the level of education effort of the group or to the status quo distribution of occupational choices. Blume \& Jayaraman (2007) present an overlapping generation model in which each generation's young trades off efficiency gains from choosing the optimal occupation against the costs of failing to conform. When social ties are strong enough, conformity may lead to occupational segregation and increase the prevalence of low-education traps for rural-urban migrants.

Anything altering the trade-off between income gains and the value of group participation will affect the incidence of the network externality. For example, a productivity shift raising wages perceived by the migrants on the market would raise the opportunity costs of community participation and lower the proportion of those willing to sacrifice education for group acceptance. In the other direction, access to a larger community at destination can be expected to increase the value of group participation, and thus the relevance of the externality on individual schooling decisions.

\section{$3 \quad$ Data and network measures}

The Thai economy experienced a rapid development process in the period under study and a substantial increase in internal migration flows during the period, with an average growth rate of real GNP per capita of 5.7\% per year between 1976 and 1996. However, the rural-urban divide grew dramatically during the same period as the income Gini coefficient rose from 0.44 in 1976 to 0.52 in 1996, a level even higher than the corresponding average for Latin America and the Caribbean in the same year (Jeong (2005)).

Figure 1 shows the raw correlation between the intensity of migration and the education level of the migrant population, using averages at the "changwat" level from multiple National

\footnotetext{
${ }^{4}$ A similar mechanism has been elegantly exposed by Austen-Smith \& Fryer (2005) who develop a two-audience signalling model in order to explain the phenomenon of "acting white", according to which young blacks in the US make a low effort in school so to reveal to their peer group that they are not mimicking whites. The group is assumed to have interest only on individuals whose social type is high, having no direct concerns with such types' educational levels. In the their model, this is formalized by assuming a fixed, non negative, payoff for the group from rejecting any individual. This anthropomorphization of the community group is consistent with other studies on social networking and under-development traps. Hoff \& Sen (2005) show that control mechanisms at disposal of the peer network can generate a poverty trap when economic opportunities outside the origin community widen. A study by Munshi \& Rosenzweig (2003), with survey data from Bombay, shows that networks of lower caste male channel boys into local language schools leading to traditional occupations, despite the substantially higher returns to nontraditional occupations.
} 
Labor Force Survey data ${ }^{5}$. Interestingly, there is an indication that localities with an higher concentration of migrants are also those hosting relatively less educated migrants.

INSERT figure 1 HERE: Migration Density and Secondary Education of Migrants, by Changwat

The data used in the empirical analysis come from a collection of research surveys of social, economic and environmental change in the district of Nang Rong, historically one of the leastdeveloped parts of Thailand. The Nang Rong project dataset consists of three waves of data collection - for the years 1984, 1994, 2000. A migrant follow-up survey was added to track a sample of migrants who had gone to one of the four following urban destinations: (1) metropolitan Bangkok; (2) the Eastern Seaboard, a highly dynamic area comprising the two urban centers of Rayong and Chonbury; (3) Korat, an important regional pole, and; (4) Buriram, the provincial capital. The 2000 round builds on the previous data collection efforts incorporating a geo-spatial component in addition to the community, household, and migrant follow-up surveys. Moreover, the 1994 and 2000 surveys undertook the innovative task to identify both social and kinship networks among the residents, households and villages of Nang Rong.

The estimations mostly rely on the life-history sections of the 2000 data, collected on the sample of individuals who are resident in Nang Rong at the time of the survey, and on the sample of those residing in one of the major urban destinations at that time. Life history, or retrospective, data provide long-term information on migration and schooling choices, yielding an unbalanced panel with a minimum of one observation for those aged 13-year-old in 2000, to a maximum of 8 observations for those aged 20-year-old or older in 2000. The analysis thus extends to multiple cohorts of individuals, and cover a period of almost 30 years. As mentioned in the introduction, the most salient aspect of these data comes from the merging of information on migrants and non migrants, which provides a picture of the rural community not bounded by the rural district and thus closer to its true, geographically mobile, configuration. Table 1 describes all the variables used in the study.

TABLE 1 HERE: List of variables

Previous research on migration and source communities has asked origin families to provide information on members who migrated. However, there are limits to the level of detail and to the quality of this indirect information. Of course, quality is also an issue for retrospective data. There are reasons to suspect recall bias especially concerning individuals who are older at the time of the 2000 survey, and thus have to reconstruct how they behaved in a distant past. However, Nang Rong surveys provide an opportunity to examine data quality because they contain repeated retrospective histories undertaken in two points in time, in 1994 and in 2000; a simple check of the matching of information provided by a subset of individuals present in both survey confirm that quality is quite high $^{6}$. Moreover, there is evidence that events that

\footnotetext{
${ }^{5}$ Changwats are the first level of Thailand's administrative subdivisions. Normalized share of migrants over total population are built using sample weights available in the Labor Force Surveys of the National Statistical Office of Thailand.

${ }^{6}$ Comparing life histories data on the whole sample from the 1994 and 2000 survey, we obtain a positive match
} 
are highly salient to the respondent, like schooling and migration decisions, are better recalled (Beckett et al. (1999)).

Network size (Net in the equations which follow) is defined by counting, for each young individual and each year, the number of co-villagers present at destination the year before ${ }^{7}$. Excluded from the count are migration episodes due to serving in the military or as a monk. The network measure is thus time varying, and specific to each village-destination couple. As already said, I assume that the village is the most relevant agora shaping social interactions outside the family, ruling out the progressive integration among villages through trade, sharing of equipment, and, most relevantly, seasonal mobility of laborers. I also exclude the members of the family that migrated from the count of the network size assigned to each individual-year, as we are mainly interested in testing the effect of acquaintances and transitory social relations.

Table 2 provides descriptive statistics on adults residing in Nang Rong (column 1), all the migrants (column 2), with disaggregation by destination. Inspection reveals the following patterns. Internal migration of women and men is similar, with the city of Khorat being the only destination where male migrants are predominant. The average level of education of parents is slightly higher for migrants than for non migrants, as well as the migrants' mean educational attainment. The average size of the migrant stock tends to be considerably higher, as expected, in traditional destinations, such as Bangkok and the provincial capital of Buriram than in new emerging poles such as cities in the Eastern Seaboard. At their first migration, movers rely on an extensive support from their communities, ranging from hospitality (three out of four go and live with others they know) to help them finding a job or for setting an entrepreneurial activity (61\% received this kind of help). Migrants are also highly successful in finding a job at destination within one month from their arrival, and they tend to move in with friends or family.

\section{INSERT table 2 HERE: Descriptive Statistics}

The last set of variables in the bottom three rows of the table gives a snapshot of the extent of origin bias in social interactions. The whole pool of migrants reveal that, at the timing of their first move, around $62 \%$ of their neighbors - people living between 100 meters where they lived - came from the region of Isan, where Nang Rong is located. This percentage lowers only to $60 \%$ when migrants are asked about their location at the year of the survey, 2000. Considering that between the year of the first move and the year 2000 there is an average interval of 11 years, this suggests that residential mixing does not occur in this sample. Statistics on the origin of friends at destination at the bottom of the table give similar indications.

Table 3 displays a transition matrix including information for all the young individuals whose

of answers on migration histories (whether one spent most of the time outside Nang Rong in a given year) around $86 \%$ of the times. In our final sample the percentage of positive matches is higher given that the average age is lower (we keep information only on individuals for whom we have data on the previous generation).

${ }^{7}$ We chose to use a count with a one year lag for two reasons: the decision of whether to migrate is probably taken with some months in advance the actual departure; moreover, with a lagged value of the network size, we should partially reduce the simultaneity problem, according to which unobserved shock affect both the network and the individual choices to migrate or to study. 
mobility and study choices are observed when between 13 and 25 years of age. It shows the number of cases in which we observe a transition along one of the four states. The matrix reveals that the sample has a fairly balanced representation of migrants and non migrants. Spotting the number of unchanged states on the diagonal of the matrix shows that there is a relatively higher number of cases of individuals studying as residents at Nang Rong than as migrants, suggesting the possibility of a schooling dispersion associated to migration.

INSERT table 3 HERE: "Transition matrix for the joint schooling mobility choice"

\section{Econometric models and results}

The econometric identification of causal effects of networks on education outcomes poses complex problems. As emphasized by Manski (1993), the fundamental problem with research on social interactions is the necessity to control for correlated unobserved effects within the community. The selection issue by which young migrants and stayers differ along unobserved characteristics is an additional complication. Our modelling approach in section 4.1 is similar to Mroz (1987): it follows a three-step approach to control for both self-selection into migration of the young and endogeneity of the network size. The bias due to the estimation on a selected sub-sample of the young population is corrected by modelling, as a first stage, the endogenous choice of moving to the city. A second step tackles the potential endogeneity of the network effect, by instrumenting network size through the exogenous variations in the number of twenty-years-old males balloted to serve in the military service and additional instruments. In the final step, the network effect is identified by a structural equation for enrollment, including both the instrumented network variable and the sample selection correction. The robustness of the results is checked in section 4.2 by estimating an alternative, multinomial optimization problem with endogeneity problems handled by controlling for unobserved individual heterogeneity through simulation methods.

\subsection{A three-step, binomial model correcting for self-selection and endogene- ity}

I discuss the methodology by tackling first the self-selection problem, then the endogeneity problem. I display the results sequentially from the naive probit estimation on the migrant subsample to our preferred specification, a structural model controlling for both self-selection and endogeneity.

\subsubsection{Step 1. Correction for self-selection into migration}

We are interested in the education decision of the young once he has reached an urban destination. The critical assumption for identification of migrant network effects on this decision is that the flow of young moving from rural to urban areas is sorted into groups according to their village of origin. This sorting is however far from being a random assignment from the whole pool of rural young. The availability of data on migrants and non-migrants allows to model 
explicitly the choice of migration as a pre-requisite for participation in group interactions. By controlling for the non-randomness of the migration choice, I correct for the likely differences between migrants and non migrants well acknowledged in the migration literature. The bias associated with non-random sorting into migrant networks is further reduced by setting up a simultaneous selection of migration destination and associated networks. Because of the dichotomy of the enrollment variable when treating the data as a pooled cross section, I follow Van de Ven \& Van Praag (1981) whose probit sample selection model is an extension of the Heckman (1979) selection model for dichotomous outcome variables.

The binary enrollment equation for a young migrant $i$ can be expressed in latent terms as follows:

$$
E_{i}^{*}=\alpha^{\prime} X_{i}+\beta^{\prime} N e t_{i}+\varepsilon_{i 1}
$$

$E_{i}^{*}$ can be interpreted as the expected utility gain from enrollment in school. In the notation above, $\beta^{\prime}$ is the main coefficient of interest, expressing the impact on schooling enrollment of variation in $\mathrm{Net}_{i}$ the size of the network of co-villagers, not members of the origin family, present at destination the year before the education decision is taken (NETWORK SIZE) ; $\alpha$ is a $K \times 1$ vector of parameters to be estimated and $X_{i}$ is a $K \times 1$ vector of time varying and constant exogenous variables, at the individual, family and village level. The vector of controls includes: the gender of the young (MALE); his age in 2000 (AGE IN 2000); the number of younger siblings (SIBLING); the average education of the parents (PARENTAL EDUCATION); family wealth at origin (ASSET SCORE); the availability of a high school at the village of origin (SCHOOL); whether more than one language is spoken at home (LANGUAGE); age dummies, city destination and origin village fixed effects, time controls, and a constant term. The error term is assumed to be normally distributed: $\varepsilon_{i 1} \sim N\left(0, \sigma^{2}\right)$.

Assume a reservation destination exists for each rural-born individual. This latent variable, expressing the expected utility gain from migrating, can be expressed as:

$$
M_{i}^{*}=\gamma^{\prime} R_{i}+\varepsilon_{i 2}
$$

where the vector $R_{i}$ includes the control variables in $X_{i}$, and the following additionnal variables: the total number of migrants from a village with one year lag (TOTAL NETWORK) and a constant term. It also includes the following variables selected as exclusion restrictions: the distance of the origin village from the main road to Nang Rong (ROAD LENGTH); a measure of family migration experience (FAMILY MIGRATION); and a family level measure of exposure to rain shocks at the origin (RAIN). The distance of the village from the main road is expected to be negatively correlated with habitants' capacity to leave. Information on and moving cost of migration are expected to decrease with family long-term migration experience. In order to reduce simultaneity concerns, the experience variable gives equal weight to the migration histories of all family members, and thus takes into account migration episodes far in the past (663 migration cases in the dataset refer to years before 1970). As shown in other studies of migration from rural areas in developing countries (see Munshi (2003) and Swee (2007)), scarce rains 
represent a serious shock to agricultural production - the culture of rice in this context - which can induce further migration. Given that there is only one meteo station collecting rain data for the whole Nang Rong region, the exposure index has been built by interacting the average yearly volume of rain in the district with the time investment of family members in agricultural activities ${ }^{8}$.

The population regression function in (1), for the subsample of migrants, can be stated as:

$$
E\left(E_{i}^{*} \mid X_{i}\right)=\alpha^{\prime} X_{i}+E\left(\varepsilon_{i 1} \mid X_{i}, N_{e t}, M_{i}^{*} \geq 0\right)
$$

The parametric assumption of the model is the bivariate standard normal distribution of $\varepsilon_{i 1}$ and $\varepsilon_{i 2}$, with correlation coefficient $\rho$. With this assumption, the error term in the outcome equation has the following conditional distribution:

$$
E\left(\varepsilon_{i 1} \mid X_{i}, N_{e} t_{i}, M_{i}^{*} \geq 0\right)=\rho \lambda_{i}
$$

where $\lambda_{i t}=\frac{\phi\left(-R_{i t}\right)}{\Phi\left(R_{i} t\right)}$, and $\phi, \Phi$ are respectively the standard normal density and cumulative distribution. As shown by Heckman (1979), the inverse Mill's ratio term $\lambda$ is a control function that must be added to the outcome equation (1) in order to estimate consistently the parameters $\alpha$ and $\beta$ :

$$
E_{i}^{*}=\alpha^{\prime} X_{i}+\beta^{\prime} N e t_{i}+\rho \lambda_{i}+\varepsilon_{i 1}
$$

The likelihood function on the subsample of migrants, after accounting for selection, can be written as:

$$
L=\prod_{i=1}^{n^{1}} \Phi^{2}\left(\alpha^{\prime} X_{i}, \beta^{\prime} N e t_{i}, \gamma^{\prime} R_{i}, \rho\right) \cdot \prod_{i=n^{1}+1}^{n^{2}} \Phi^{2}\left(-\alpha^{\prime} X_{i}, \beta^{\prime} N e t_{i}, \gamma^{\prime} R_{i}, \rho\right) \cdot \prod_{i=n^{2}+1}^{N} \Phi\left(-\gamma^{\prime} R_{i}\right)
$$

$\alpha$ and $\rho$ can be consistently estimated using the Heckman two step procedure, or by a full maximum likelihood approach ${ }^{9}$. The enrollment equations are estimated on repeated annual observations for 776 young individuals between 13 and 19 years old, yielding an unbalanced panel of 2164 cases (one case corresponding to the pair individual-year). The selection equation is estimated on a sample of 5961 observations referring to 1355 young.

The main variable of interest, the origin village migrant network size, has a statistically significant negative impact on enrollment both in the benchmark probit model and in the probit model corrected for migrant self-selection; this negative impact is confirmed when we control for origin village fixed effects. Because of pooled data with $t$ observations for each individual,

\footnotetext{
${ }^{8}$ Rain data come from the Thailand Meteorological Office, and cover all years starting 1970 . The time investment in agriculture is computed by counting, for all adult family members, the number of years they spent working as peasants, starting from the age of 13, and dividing this number by their age minus 13 .

${ }^{9} \mathrm{I}$ opt for the second one estimating the model through the heckprob command in STATA. See the STATA reference manual (2007) for details on the command.
} 
standard errors need to be corrected for the likely intra-group (individual) correlation. This is done through the cluster variance estimator (see STATA (2007)).

Results are displayed in table 4. Columns 1 and 2 first show results from a simple probit model, not accounting for self selection into migrant status. Column 2 includes village fixed effects so that the identification of the network effects relies on changes in migration investments across communities while we control for fixed, unobserved characteristics of the communities. Columns 3 and 4 display results for the same probit models once we control for self-selection into migration.

INSERT table 4 here: "School enrolment model with selection into migration"

There is no strong evidence of gender effects either on the propensity to pursue higher schooling or to migrate when young. Having educated parents raises the odds of being enrolled in school after the age of 13 , while being (weakly) negatively correlated with internal migration of the young. Speaking more than one language at home has no significant effects on schooling, while it is positively correlated with migration propensity: no one-way causal relation can be established here, since the fact of speaking more than one language at home can be associated with a family history of migration or interethnic marriages. In order to control for family wealth while reducing evident endogeneity concerns, I build a principal component measure of family long term income, condensing information on twelve productive and non productive assets. This wealth measure has a significant, positive explanatory power on the odds of enrollment, while it is not a significant determinant of young migration choices. Having more younger brothers and sisters does not affect schooling choice once one has controlled for wealth, suggesting no competition for scarce resources among siblings. However, coming from a larger family seems to affect positively the willingness to migrate. With respect to those migrating to Bangkok, enrollment rates are higher for the young who moved to Buriram (the regional capital).

As to the variables excluded for identification reasons, observe that the exposure to rain variability, due to concentration of family activity in rice production, acts as an important push factor for individual migration ${ }^{10}$. The overall migration investment of the village (obtained by counting together migrants from the village present in all the destinations with one year lag and weighting this measure by the sampled village population) is a highly relevant predictor of individual migration. Finally, the cumulated number of years of working experience outside Nang Rong of family members not in the estimation sample (30 years old or older), is another important explanatory factor of the migration of the young.

A potential drawback to the application of Heckman's selection model is its sensitivity to the assumed parametric distribution of the unobservable error terms in the model. If the joint distribution of the error terms is misspecified, the second-step parameter estimator will,in general, be inconsistent. Newey et al. (1990) conditions on a polynomial of the estimated probability of participation in a regression framework, in order to avoid to impose parametric forms on error

\footnotetext{
${ }^{10}$ This has been shown convincingly for Nang Rong data by Swee (2007), who build a measure of exposure to rain shock by interacting rain intensity with a estimated probability of being a net rice producer.
} 
distributions. This flexible function of the estimated probability approximates the unknown conditional expectation of the error term, just as the Mills ratio terms, which are functions of the probability of participation, represent the conditional expectation of the unobservables under the normality assumption. Table 4, column 5 reports the results when the selection model is estimated semi-parametrically in two steps as suggested by Newey et al. (1990), using a quartic in the predicted probability of migration to approximate the true control function: the statistical significance and the size of the coefficient for network size are not much altered ${ }^{11}$.

\subsubsection{Step 2. Correction for endogeneity of the network size variable}

Controlling for self-selection in the migration status is not enough to achieve consistent identification of network effects if we have reasons to suspect the endogeneity of the network size variable in the individual schooling model. Three variations of the same statistical problem need to be considered: measurement error, simultaneity bias and omitted variable bias. Essentially, all three challenge the consistency of the model, pointing to the possibility that the network size regressor can be correlated with unobserved determinants of the enrollment choice. Measurement error is an issue, since we dispose of an imperfect proxy of the true size of the network from the origin community: given that villages are not isolated from one another, and that solidarity or mutual recognition can link individuals at a higher level than the village, it is possible that our variable measures the effective network with error. This error can be correlated with unobserved characteristics of the young mediating the network effect, since less able individuals might search for network connections outside their own origin village. Simultaneity bias can be a further threat to the consistency of network effect estimation. The choice of youngsters to be enrolled in school can be internalized by the community, which might then transfer information on job opportunities in the city to those who are still in the village. By this mechanism, network size might not only cause but also be influenced by schooling behavior. Finally, omitted variable bias is probably the greatest source of concern, since we are not able to control for the full set of unobserved factors and shocks affecting both movements from the villages to the cities and the human capital accumulation of individuals who are part of this flow. In particular, unobserved shocks in the return to schooling at destination can be associated with changes in the relative profitability for the young of joining a larger network. The following simultaneous estimation helps deal with these issues:

$$
E_{i}^{*}=\beta^{\prime} W_{i}+e_{i}=0
$$

\footnotetext{
${ }^{11}$ As stressed by Newey et al. (1990), this and other variants of semi-parametric estimators of the selection model would require some mechanism to choose the amount of "smoothing" imposed (here number of basis functions). I am not aware of any "rule of thumb" providing clear guidance on the length of the polynomial, and the quartic function has been simply chosen after testing for significance of alternative control functions. Moreover, results of the semi-parametric estimation of the selection model are only provided as a robustness check, since the two-step estimation of binary response models is problematic: the likelihood in the second step is biased, and the extent of the bias is proportional to the size of the correlation between the error terms of the two equations.
} 


$$
N e t_{i}=\zeta^{\prime} Z_{i}+u_{i}
$$

where $W_{i}=\left(X_{i}, \widehat{N e t}_{i}\right)$, with $X_{i}$ being the usual set of controls and $\widehat{N e t}$ being the fitted values from the network instrumented equation (7), i.e. $\widehat{N e t}_{i}=\widehat{\zeta}^{\prime} Z_{i}$. The instruments in the vector $Z_{i}$ are expected to satisfy the requirements of exogeneity and relevance.

The $\log$ likelihood for observation $i$ is:

$$
\ln L_{i}=E_{i} \ln \Phi\left(m_{i}\right)+\left(1-E_{i}\right) \ln \left[1-\Phi\left(m_{i}\right)\right]+\ln \phi\left(\frac{N e t_{i}-\zeta^{\prime} Z}{\sigma}\right)-\ln \sigma
$$

with

$$
m_{i}=\frac{\beta^{\prime} W_{i}+\rho\left(N e t_{i}-\zeta^{\prime} Z_{i}\right) / \sigma}{\left(1-\rho^{2}\right)^{\frac{1}{2}}}
$$

The model is estimated using the IVProbit procedure in Stata which implements Amemiya's generalized least square estimator (Amemiya (1978); Newey (1987)), jointly estimating equations (6) and (7) via maximum likelihood where endogenous variables are treated as linear functions of their instruments as well as other exogenous variables. Standard errors are corrected for the correlation induced by the fact that individuals are observed over multiple periods. The proposed instruments in $Z_{i}$ are: 1) the proportion of young males (at the ages of 20-21) in the village who are balloted to serve in the military outside Nang Rong (MILITARY); 2) the exposure of the village to rain shocks (RAIN VOLUME); 3) the incidence of return migration to the village (RETURN). Regarding recruitment into military service, it was by ballot in Thailand until 1998, as the number of liable conscripts was far higher than the number needed by the armed forces ${ }^{12}$. Call-up took place once a year and each district was given a quota for the number of recruits needed by the armed forces. Eligible males had to participate in the ballot and those who drew a red ticket had to perform military service, leaving the village of birth for up to two years.

The random departures of the young imposed by the ballot system are likely to represent an external variation of information on living and working opportunities outside Nang Rong. Inspection of the data in figure 2 suggests that there is a significant correlation between the stock of migrants in a given year and the number of young balloted for the military the year before: migrant networks can be strenghtened directly by those young who choose not to go back to the village when the conscription period has expired, or indirectly by the information provided by conscripted movers to those considering the possibility to migrate. As is well known, instrumental variables need to satisfy not only the requirement of relevance but also the one of instrumental exogeneity: restricting the relevant sample to individuals who are 19 years old or younger, we can believe that the randomized village-level participation of the young in the

\footnotetext{
${ }^{12}$ Conscription was introduced in Thailand shortly after the First World War. In the 80s and 90s the recruitment system increasingly became subject to public debate. Obviously the system was likely to lead to favoritism on the hands of influential or rich people. We expect this favoritism to be less pronounced within the less developed rural areas of Nang Rong, and thus that young villagers had to face more or less the same risk of being recruited for the military. See the military recruitment dataset at: http://leavwww.army.mil/fmso/documents/mildat/RecruitmentCodebook.pdf
} 
military has no independent effects on schooling choice of the young not liable for serving in the army.

INSERT figure 2 HERE: Correlation Between Village Migration and Military Conscriptions

Regarding exposure to rainfall shocks, the village level measure is built by interacting the level of rainfall with the village-level average time investment in agriculture. The exogeneity of this second instrument can be reasonably assumed if we think that shocks at the origin village have no other impact on schooling choices of young migrants in the city apart from altering the size of their relevant network ${ }^{13}$.

The last instrument is a count of episodes of return from each destination to village of origin: the relevance of this instrument is straightforward, as substantial episodes of return are observable once the village starts to have a relevant migration history. I use a two-year lagged value of this return variable to reduce the threat to validity represented by unobserved factors or shocks likely to affect both village-level return behavior and individual schooling decisions at destination. Again, the assumption here is that the schooling choices at destination of young migrants are affected by returns of people outside their family only through the variation in size of their community network.

\subsubsection{Step 3. Structural model accounting for both self-selection and endogeneity}

As both self-selection of the young as migrants and the endogeneity of the network variable are deemed important for identification of the network effect, I propose a model able to account for both problems by rewriting the outcome (eq. 1), the instrumenting (eq. 7) and the selection (eq. 2) equations as a system:

$$
\begin{aligned}
E_{i} & =1\left(\alpha^{\prime} X_{i}+\beta^{\prime} N e t_{i}+\varepsilon_{i 1}>0\right) \\
N_{e} t_{i} & =\zeta^{\prime} Z_{i}+u_{i} \\
M_{i} & =1\left(\gamma^{\prime} R_{i}+\varepsilon_{i 2}>0\right)
\end{aligned}
$$

allowing arbitrary correlation among the three error terms.

An estimating equation can be easily derived from the system:

$$
\left.E_{i}=1\left[\alpha^{\prime} X_{i}+\beta^{\prime} N e t_{i}+g\left(R_{i}, M_{i}\right)+v_{i}\right]>0\right)
$$

where $g\left(R_{i}, M_{i}\right)=E\left(\varepsilon_{i 1} \mid R_{i}, M_{i}\right)$.

As shown by Mroz (1987), two stage least square (TSLS) estimation provides consistent estimates of $\beta$ if at least two valid instruments are available ${ }^{14}$.

\footnotetext{
${ }^{13}$ The exogeneity of this second instrument can be challenged: if shocks at the origin alter demands of staying villagers for support by their family migrants, then the need to remit more can explain a change in labour supply of the young. However, this instrument is not crucial for acheiving identification, and it is excluded from all the regressions with village fixed effects.

${ }^{14}$ The non linearity in the Mills ratio, estimated through probit, could provide identification even with a single
} 
INSERT table 5 HERE: "IV Estimation of network effects on schooling enrolment"

Results are displayed in table 5. Columns 1 and 2 are different specifications of the AmemiyaNewey instrumental variable probit model, the second including village fixed effects. Columns 3 and 4 report TSLS (linearized) estimates, respectively with and without village fixed effects. In all specifications, network size enters as a negative and significant determinant of schooling enrolment. Taken together with those in table 4, I interpret these results as strong support for the hypothesis that young individuals, when migrating, have a lower propensity to acquire an higher level of education if they are part of a large enclave.

Regarding the instrumental variables, the lagged number of drafted soldiers is strongly correlated with the size of the network in all the specifications. The number of episodes of return at period $t-2$ are a highly significant and positive predictor of the stock of migrants at any destination at period $t-1$. Rain intensity, as expected, reduces out-migration from the village, even if its statistical significance drops when we add village fixed effects to the model specification. This instrument becomes redundant given the collinearity with the fixed effects, so we can omit it (column 4) and still meet the conditions for identification. In all the specifications, the combined instruments pass weak identification tests ${ }^{15}$. A test of overidentifying restrictions shows that the null of instrument exogeneity can not be rejected (the Hansen J statistics for the 2SLS model with selectivity correction (4) has a value of 0.58 , which corresponds to a P-value of 0.45$)$.

Regarding the magnitude of the impact, a one standard deviation increase in network size corresponds to a decrease in the probability of enrollment of $6.6 \%$ in the three-stage model (column 4). It is interesting to observe that the size of the estimated effect doubles in the threestage model with respect to a simple linear probability model with village fixed effects. This change could reflect the role of unobservables. First, unobserved ability or taste for schooling could be a relevant omitted variable. This unobservable is likely to be negatively correlated with network size, as those with less ability would rationally choose destinations with larger networks, thus biasing $\beta^{\prime}$ in (5) downwards. Similarly, networks can become more dispersed as unobserved shocks raise returns to schooling in urban areas. The fact that the benchmark model cannot fully account for this endogenous network development could explain a downward biased coefficient ${ }^{16}$.

instrument. In practice, this is unlikely to work well because of collinearity problems, as explained in Wooldridge (2002). It would be possible to estimate the model by partial maximum likelihood rather than with 2SLS, but this would require strong assumptions on the joint distribution of the three error terms. Angrist (2001) argues that the common use of parametric models overly complicates inference when the statistic of interest is causal effects and suggests that linear approximation like standard 2SLS performs as well as parametric estimators in a labor-supply model. A potential source of bias is given by the fact that we are including an estimated regressor, the inverse Mills ratio. However, one cannot easily implement a standard error correction for two-stage models à la Murphy and Topel, given the use of a cluster variance estimator.

${ }^{15}$ For the specification in (4), the Kleibergen-Paap Wald F-statistic has a value of 39.585, largely above the critical values specified in Stock \& Yogo (2005). This clearly indicates that the estimations do not suffer from the weak instrument problem.

${ }^{16}$ Of course, here the discussion can not be easily generalized. In different contexts, another framework can be more appropriate, according to which migrants'flows increase when returns of schooling at destination increase. 
INSERT table 6 HERE: "Additional robustness checks":

Table 6 provides robustness check for the three-stage model above. Column 1 reports the estimates of the same model on the larger sample of young between 13 and 25 years old. The size of the network coefficient decreases but it is still statistically significant. Column 2 shows that the estimated network effect is not very sensitive to the inclusion of other time-varying covariates at the village level: the mean education level of the network population, and the average wage of covillagers at their first job at destination. Given their likely endogeneity, no causal interpretation should be assigned to the coefficients of these two additional regressors. Finally, in column 3, migrants to the regional capital of Buriram are excluded from the sample. Those migrating to this city might in fact face a different assimilation process, given closeness and lower ethnical diversity of this destination with respect to Nang Rong villages. As expected, the statistical significance of the network variable increases.

\subsection{Controlling for unobserved heterogeneity: a multinomial model for the joint schooling and migration decisions}

It is possible to control for unobserved heterogeneity by exploiting the availability of repeated observations for each individual. Given that we dispose of data on both migrants and non migrants, a convenient way of checking the robusteness of previous results is to redefine the model as a multinomial one. I restrict the focus to a particularly convenient class of multinomial models, the mixed logit or logit Kernel model (Ben-Akiva et al. (2001), Prowse (2005)). Each young $i$ rationally chooses one of the four options $j$ - defined by the interaction of residential status (migrant to an urban destination or stayer in Nang Rong) and enrollment choice (study or work) - to maximize his payoff $V$ in each period $t$.

$$
\begin{array}{rll}
\text { Migrate and Study } & : & V_{i, 1, t}=\alpha^{\prime} X_{i 1 t}+\beta^{\prime} N e t_{i 1 t-1}+\eta_{i, 1}+\epsilon_{i, 1, t} \\
\text { Migrate and Work } & : & V_{i, 2, t}=\alpha^{\prime} X_{i 2 t}+\beta^{\prime} N e t_{i 2 t-1}+\eta_{i, 2}+\epsilon_{i, 2, t} \\
\text { Stay and Study } & : & V_{i, 3, t}=\alpha^{\prime} X_{i 2 t}+\beta^{\prime} N e t_{i 2 t-1}+\eta_{i, 3}+\epsilon_{i, 3, t} \\
\text { Stay and work } & : & V_{i, 4, t}=\epsilon_{i, 4, t}
\end{array}
$$

$X$ is the vector of controls, $N e t_{t-1}$ is the network variable and the fourth option $V_{i, 4, t}$ (Stay in Nang Rong and Work) is chosen as the reference category, relative to which the parameters $\alpha$ and $\beta$ in the first three equations are interpretable. The time invariant random effects $\left(\eta_{1}, \eta_{2}, \eta_{3}\right)$ are assumed to be jointly normally distributed with zero mean and covariance matrix $\Sigma$.

This specification endogenizes the location of residence decision with decisions in each period about going to school, controlling for unobserved heterogeneity across individuals. Estimation is carried out by maximum simulated likelihood. To understand the intuition behind this simulation method, observe that the unconditional log-likelihood can be interpreted as an expected In this case, the same simultaneity problem should rather bias the estimate of the network effect upward. 
value:

$$
\ln L=\sum_{i=1}^{N} \log E_{S}\left[\left(\frac{\exp \left(\alpha^{\prime} X_{i 1 t}+\beta^{\prime} N e t_{i 1 t-1}+\eta_{i, j}\right)}{\sum_{k=1, . . J} \exp \left(\alpha^{\prime} X_{i 1 t}+\beta^{\prime} N e t_{i 1 t-1}+\eta_{i, j}\right)}\right)^{Y_{i, j}}\right]
$$

Simulation proceeds by sampling $R$ times from the distribution of $\eta_{i}$ and constructing joint probability of the individual's observed sequence $P_{i}\left(\eta_{i}^{r}\right)$ for $r=1 \ldots . R$. The individual simulated likelihood are obtained by averaging $P_{i}\left(\eta_{i}^{r}\right)$ over the $\mathrm{R}$ draws ${ }^{17}$. Results are displayed in table 7 .

\section{INSERT Table 7 HERE "Mixed Logit estimation of Network effects"}

The first set of columns (1) reports the results with random intercepts, all other variables having their coefficients kept fixed. The second set of columns (2) allows for correlations and heteroscedasticity in the within-period and between-period unobservables affecting the individual's payoffs from each alternative ${ }^{18}$. As shown (see Prowse, 2005), this additional flexibility can be important as estimates of individual characteristics are sensitive to the assumed distribution of unobservables. The third set of columns (3) displays results of a fixed effect estimation with uncorrelated random intercepts and the final set of columns (4) includes correlated random intercepts and village fixed effects. Coefficients need to be interpreted with respect to the baseline alternative, staying in Nang Rong as a worker. For example, looking at the coefficients for family wealth (proxied by the asset score), one can see that those studying at destination come from relatively wealthier families. Those migrating for working tend to have a less wealthy background with respect to those who stay and find an employment in their origin region.

Concerning the network effect, there is evidence of a significant impact of the migrant network size on preferences for employment or education for those leaving their village. The young with a larger network tend to migrate and start working more at destination while they exhibit a lower preference for moving and studying in the city. To have an intuition on the magnitude of this effect, consider a discrete change in the network size in the model in columns (4): a one standard deviation increase in the size of the network (a one third increase of individuals present at destination) increases the probability of choosing the option of migrating and working by $1,8 \%$, while decreasing the probability of choosing to migrate and study by $3,9 \%$, when these two options are evaluated with respect to the baseline choice of staying in the origin village to work. There is also a significant effect of network size on the choice of studying rather than working while staying in Nang Rong. However, this estimated effect is very small (one standard deviation change in network size affecting the relative probability of studying at origin by only

\footnotetext{
${ }^{17}$ Several simulation methods exist for sampling from the distribution of $\eta_{i}$; we here use Halton draws, which have been shown to provide an high level of accuracy for a relatively low computational time (Train (2000)). The model is estimated on STATA using the mixlogit routine developed by Hole (2007).

${ }^{18}$ Heteroskedasticity in the random intercepts basically means that there are different amounts of unobserved variation in youngs' preferences for the three alternatives (stay and study, migrate and study, migrate and work), relative to the baseline of stay in Nang Rong for working. Similarly, correlation between the random unobservables allows for positive or negative associations in youngs' preferences for the three alternatives relative to the baseline. This is a significant departure of the mixed multinomial model with respect to the standard multinomial logit model, which suffers, as known, from the independence from irrelevant alternatives property.
} 
$0,3 \%)$.

\section{Conclusions}

In developing countries, the divide between trapped rural regions and dynamic urban poles has widened in recent years, and so location of birth persists to be an important predictor of economic opportunities. Different economic models have illustrated how this opportunity gap is destined to shrink when mobility is not constrained by high migration costs. However, this is clearly true only if labor markets at destination do not segmentate in niches separating migrants from natives, and if migrants are perceived and behave at destination labor market as the natives do. Common observation, and our data from Thailand, indicate that migrants tend to concentrate in enclaves at destination, and networks as informal institutions have an important role in smoothing assimilation to urban life, either by promoting solidarity and risk sharing among their members, either by easing employment matching.

This paper has investigated the dynamic implications of the social ties linking young migrants to their own community of origin with regard to their educational decision. Assuming that higher and technical education is needed for talented individuals to reap the full opportunities of booming cities, I argued that a simple test of network effects on economic mobility can be undertaken by regressing network size (as a proxy for density of the community ties and for the probability that networks are active and effective) on the probability of the young to be enrolled as students at destination.

I implemented this test using a panel dataset which accurately describes migration and career choices of both stayers and movers in Thailand. A three-step estimation method was used to take advantage of the characteristics of the data set and correct for self-selection in the migration choice and possible endogeneity of the network effect with community network sizes being instrumented by the random variation of young men balloted into the military service. I found a statistically significant negative relation linking young migrants' schooling decision with the size of the network of co-villagers present at destination. These results were upheld when shifting to an alternative multinomial specification, which allows a straightforward accounting of individual heterogeneity.

The paper thus provides evidence of a channel which can lead to persistence of low educational attainment for those born in rural areas. This finding has important implications for policies attempting to rise schooling participation: young migrants integrated in sufficiently large enclaves might perceive a higher opportunity cost of schooling and will tend to join the labor force earlier. Since migrant networks are not likely to lose in importance as rural urban integration proceeds, there is the need to study better why the clustering in solidal networks might undermine investment in education at destination.

Two explanations deserve mention. A first links the migrant network size with the development of asymmetric or stratified communities within the city. Given an initial disadvantage 
with respect to natives, young migrants end up living in less dynamic neighborhoods. Labor market institutions specific to these heterogenous communities - and in particular the wordof-mouth mode of dissemination of information about scarce job opportunities - are likely to play a role as individuals belonging in low skill networks develop lower expected returns to high education acquisition (Anderberg \& Andersson (2007)). According to the second explanation, the community effectively discourages the acquisition of higher education by their members, as this behavior is perceived as a deviation from the community's social norms and is sanctioned.

A policy maker interested in raising educational achievements of the young migrants should sensibly think about measures affecting the community evaluation of higher schooling, such as reserving preferential access of migrants to training and matching programs. It might also be worth experimenting with policy measures reducing the dependency of young individuals on support of their own origin community (for example, scholarship schemes involving the physical deplacement of the young to neighborhoods where concentration of their co-villagers is lower). Evaluations of programs providing transfers to randomly selected families in disadvantaged neighborhoods to move to more affluent areas show significant improvement in outcomes for the young (see, for example, Kling et al. (2005)). One can further surmise that what holds for internal migration is potentially even more valid for international migration as the value attached by an individual to participation in his community group should rise as the costs of migration and assimilation rise. 


\section{References}

Amemiya, T. (1978), 'The estimation of a simultaneous equation generalized probit model', Econometrica 46(5), 1193-1205.

Anderberg, D. \& Andersson, F. (2007), 'Stratification, social networks in the labour market, and intergenerational mobility', Economic Journal 117(520), 782-812.

Angrist, J. D. (2001), 'Estimations of limited dependent variable models with dummy endogenous regressors: Simple strategies for empirical practice', Journal of Business $\mathcal{E}$ Economic Statistics 19(1), 2-16.

Austen-Smith, D. \& Fryer, R. G. (2005), 'An economic analysis of "acting white"', The Quarterly Journal of Economics 120(2), 551-583.

Banerjee, B. (1983), 'Social networks in the migration process: Empirical evidence on chain migration in india', Journal of Developing Areas 17(2), 185-96.

Beckett, M., DaVanzo, J., Sastry, N., Panis, C. \& Peterson, C. (1999), The quality of retrospective reports in the malaysian family life survey, Technical report.

Ben-Akiva, M., Bolduc, D. \& Walker, J. (2001), Specification, estimation, identification of the logit kernel (or continuous mixed logit) model, Working paper, Massachussets Institute of Technology.

Benabou, R. (1996), 'Equity and efficiency in human capital investment: The local connection', Review of Economic Studies 63(2), 237-64.

Blume, L. \& Jayaraman, R. (2007), 'Social identity and economic performance', CESifo Working Paper.

Borjas, G. J. (1995), 'Ethnicity, neighborhoods, and human-capital externalities', American Economic Review 85(3), 365-90.

Bowles, S. \& Sethi, R. (2006), Social segregation and the dynamics of group inequality, Working Papers 2006-02, University of Massachusetts Amherst, Department of Economics.

Eckstein, Z. \& Weiss, Y. (1998), The absorption of highly-skilled immigrants: Israel, 1990-1995, CEPR Discussion Papers 1853, C.E.P.R. Discussion Papers.

Friedberg, R. M. (2000), 'You can't take it with you? immigrant assimilation and the portability of human capital', Journal of Labor Economics 18(2), 221-51.

Godley, J. (2001), 'Kinship networks and contraceptive choice in nang rong, thailand', International Family Planning Perspectives 27(1). 
Heckman, J. J. (1979), ‘Sample selection bias as a specification error', Econometrica 47(1), 15361.

Hoff, K. \& Sen, A. (2005), The kin system as a poverty trap?, Policy Research Working Paper Series 3575, The World Bank.

Hole, A. R. (2007), 'Fitting mixed logit models by using maximum simulated likelihood', Stata Journal 7(3), 388-401.

Jeong, H. (2005), Assessment of relationship between growth and inequality: Micro evidence from thailand, IEPR Working Papers 05.20, Institute of Economic Policy Research (IEPR).

Kling, J. R., Liebman, J. B. \& Katz, L. F. (2005), Experimental analysis of neighborhood effects, NBER Working Papers 11577, National Bureau of Economic Research, Inc.

Manski, C. F. (1993), 'Identification of endogenous social effects: The reflection problem', Review of Economic Studies 60(3), 531-42.

Mills, M. B. (1997), 'Contesting the margins of modernity : women, migration and consumption in thailand', American Ethnologist 24(1), 37-61.

Mroz, T. A. (1987), 'The sensitivity of an empirical model of married women's hours of work to economic and statistical assumptions', Econometrica 55(4), 765-99.

Munshi, K. (2003), 'Networks in the modern economy: Mexican migrants in the u.s. labor market', The Quarterly Journal of Economics 118(2), 549-599.

Munshi, K. D. \& Rosenzweig, M. R. (2003), 'Traditional Institutions Meet the Modern World: Caste, Gender and Schooling Choice in a Globalizing Economy', SSRN eLibrary .

Newey, W. K. (1987), 'Efficient estimation of limited dependent variable models with endogenous explanatory variables', Journal of Econometrics 36(3), 231-250.

Newey, W. K., Powell, J. L. \& Walker, J. R. (1990), 'Semiparametric estimation of selection models: Some empirical results', American Economic Review 80(2), 324-28.

Prowse, V. (2005), State dependence in a multi-state model of employment, Economics Papers 2005-W20, Economics Group, Nuffield College, University of Oxford.

STATA (2007), Base Reference Manual, STATA PRESS.

Stock, J. H. \& Yogo, M. (2005), 'Asymptotic properties of the hahn-hausman test for weakinstruments', Economics Letters 89(3), 333-342.

Swee, E. L. (2007), Network effects among migrants in the labour market: evidence from thailand, Working paper. 
Tapananont, N. (2004), Socio-economic mixed in bangkok urban regeneration, University of tokyo, september 2004, Report at the International Workshop on Sustainable Urban Regeneration.

Train, K. (2000), Halton sequences for mixed logit, Economics Working Papers E00-278, University of California at Berkeley.

Van de Ven, W. P. M. M. \& Van Praag, B. M. S. (1981), 'The demand for deductibles in private health insurance : A probit model with sample selection', Journal of Econometrics $\mathbf{1 7}(2), 229-252$.

Wooldridge, J. (2002), Econometric Analysis of Cross Section and Panel data, The MIT Press.

Yamauchi, F. (2003), Are experience and schooling complementary?, Technical report. 

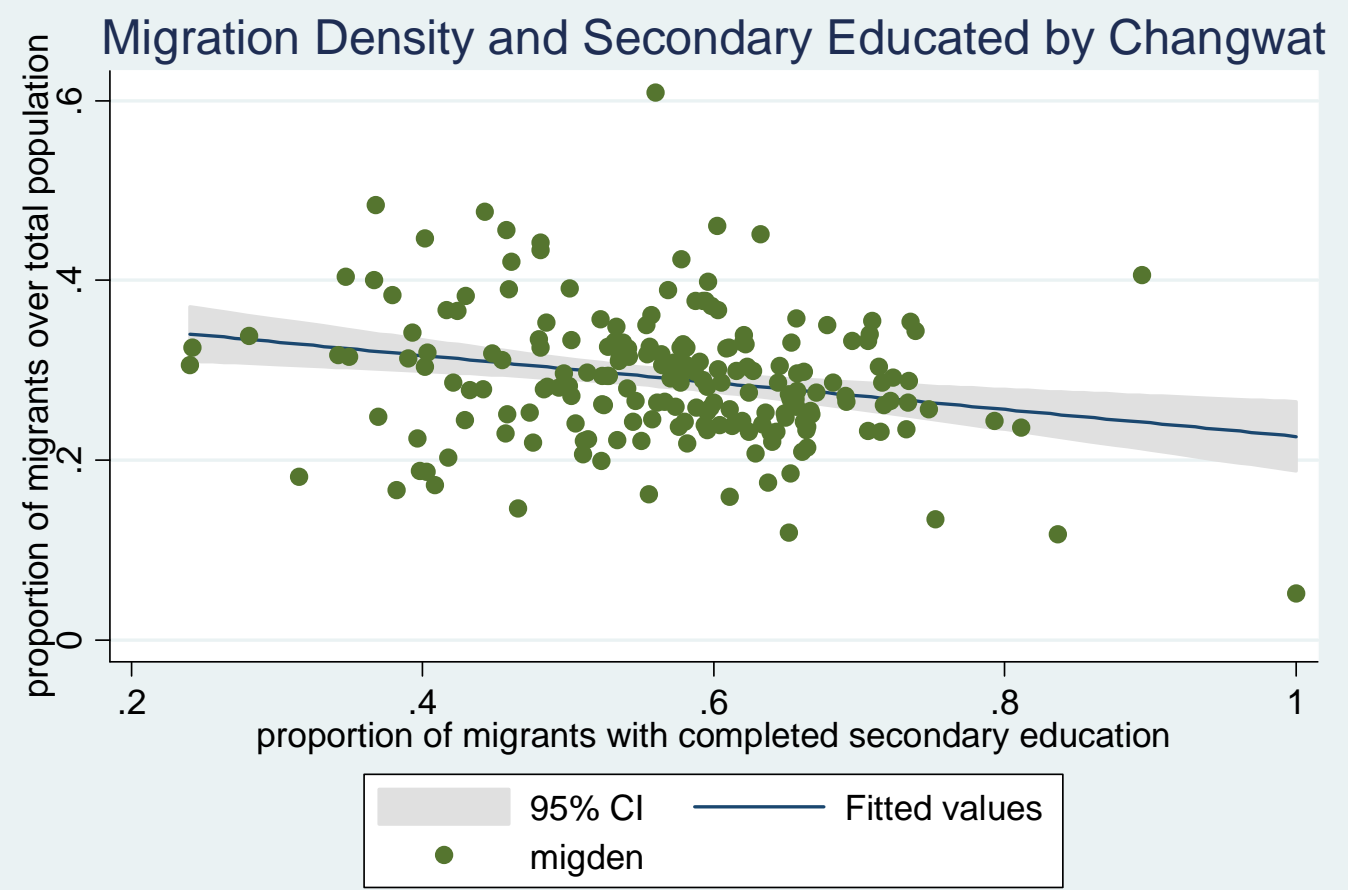

Based on 10 waves of 3rd Round data of Labour Force Surveys (1991-2000)

Figure 2. Correlation between village migration and military conscriptions

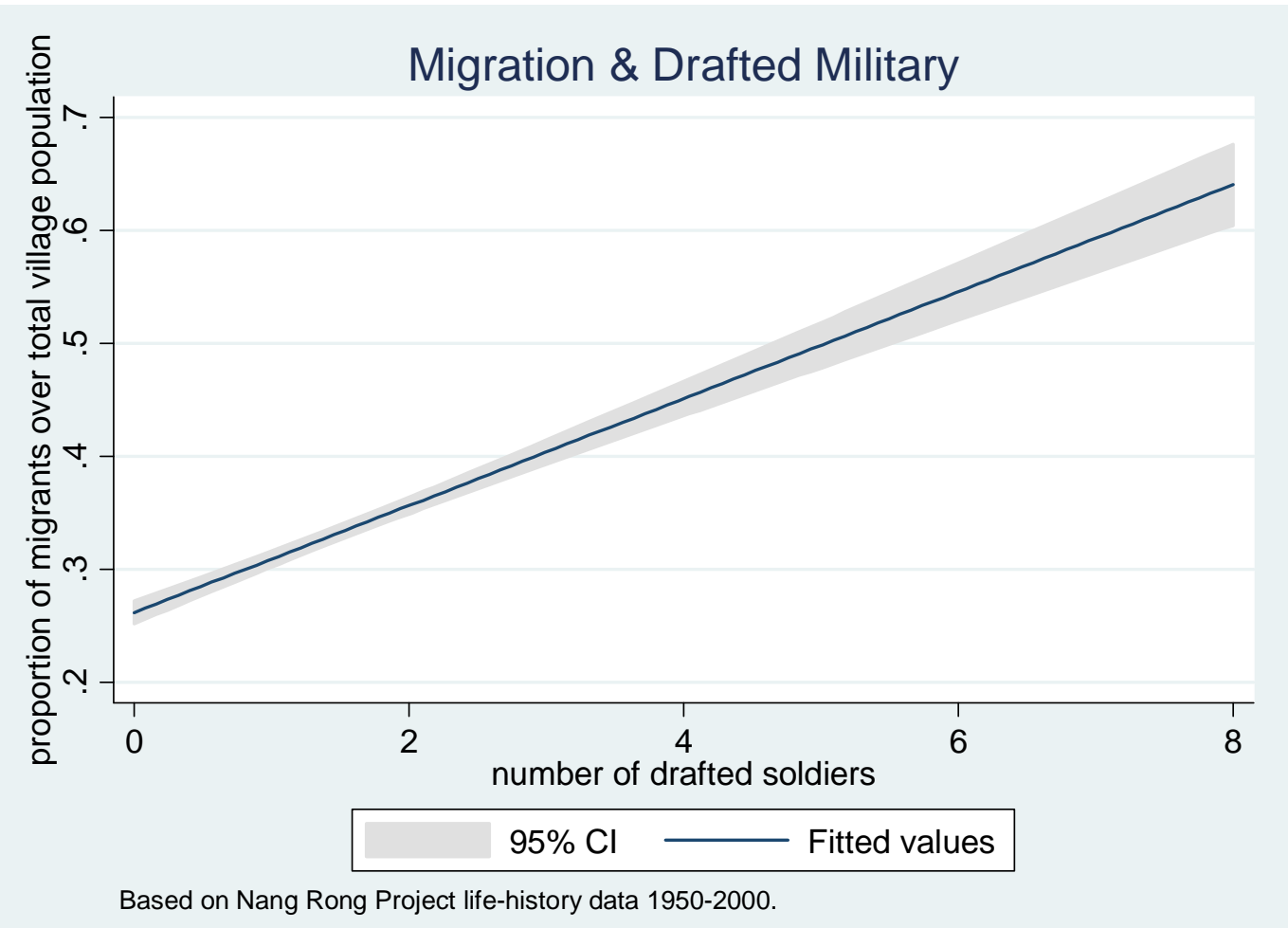


Table 1. List of variables

\begin{tabular}{|c|c|}
\hline Variable & $\begin{array}{l}\text { Description } \\
\text { Dependent variables }\end{array}$ \\
\hline Student & 1=Enrolled as student, $0=$ Not Enrolled \\
\hline \multirow[t]{2}{*}{ Migrant } & 1=Living in a urban destination, $0=$ Living in a Nang Rong Village \\
\hline & Main explanatory variables \\
\hline Network Size & $\begin{array}{l}\text { Number of year/destination/village specific established migrants. In all regressions it is } \\
\text { computed with one year lag. For each young, migrants from his own family are excluded } \\
\text { from the count }\end{array}$ \\
\hline Total Network & $\begin{array}{l}\text { Number of year/village specific established migrants, divided by the total sampled village } \\
\text { population. In all regressions it is computed with one year lag. For each young, migrants } \\
\text { from his own family are excluded from the count }\end{array}$ \\
\hline Family Migration & $\begin{array}{l}\text { Family average of adult - } 30 \text { year-old of older - individual migration histories (years spent } \\
\text { outside Nang Rong/years of adult life( } 14 \text { years old or more)) }\end{array}$ \\
\hline Network's education & $\begin{array}{l}\text { Destination/village specific average of years of education completed by established } \\
\text { migrants. Computed with one year lag. }\end{array}$ \\
\hline \multirow[t]{2}{*}{ Road length } & $\begin{array}{l}\text { Distance in kilometres of the origin village from the main road to the town of Nang Rong in } \\
1984\end{array}$ \\
\hline & Instrumental variables \\
\hline
\end{tabular}

\begin{tabular}{ll}
\hline Military & Number of drafted soldiers who left the village, inserted in all regressions with two years \\
& lag \\
Rain volume & Year average of monthly measures (in ml) of rain fallen in Nang Rong, interacted with \\
& averages (at village or household levels) of labor supply in agriculture (years spent \\
& working in agriculture /years of adult life (14 years old or more)). \\
& Number of Individuals returning to the village from one urban destination, inserted in all \\
Return & regressions with two years lag.
\end{tabular}

Main control variables

\begin{tabular}{ll}
\hline Actual age & Age of the young at each period of the panel \\
Age in 2000 & Age of the young when interviewed for the 2000 survey \\
Buriram & $0=$ young lives in Buriram province, 1=young does not live in Buriram province \\
Eastern Seaboard & $0=$ young lives in Rayong or Chanbury, 1=young does not live in Rayong or Chanbury \\
Khorat & $0=$ young lives in Khorat, 1=young does not live in Khorat \\
Language & $0=$ more than one language is spoken at home, $1=$ only one language is spoken at home \\
Male & $0=$ female, $1=$ male \\
Other destination & 0= young does not live in any Thai destination other than Bangkok, Khorat, Eastern \\
& Seaboard or Buriram at a given age; $1=y$ oung lives in another destination \\
Parental education & Average years of formal education completed by the parents. Years of education \\
& completed by the father (the mother), if only information on the father (the mother) is \\
& available
\end{tabular}

Siblings

School

Number of living younger brothers and sisters

Single

$1=$ there is a secondary school in origin village in the relevant year; $0=$ there is no such school in origin village

Asset score $0=$ married; $1=$ not married

Principal component wealth score obtained by using 1984 data on origin family's ownership of the following assets: television, recorder, telephone, refrigerator, computer, washing machine, motorcycle, car and truck, extension of plots cultivated.

Average Wage Deflated village-level average of salaries of migrants' at their first job at destination Other descriptive variables

Salary
Support

Education completed Family at destination

Money received

Money sent

Others came

Others living

Job in 1 month

Education completed Neighbours from Isan
Deflated migrant's hourly wages (in bath) at first migration

1= migrant received help to find a job or to set up an entrepreneurial activity by family or friends, at his first migration; $0=$ migrant did not receive this help

Years of formal schooling completed

$1=$ migrant has family members present at destination at the time of his first migration, $0=$ no family members present

Money (in bath) received from origin family during the first migration year

Money (in bath) sent to the family in the village during the first migration year

$1=$ migrant moved with others at his first migration, 2=migrant moved alone

$1=$ migrant lived with family or friends at first migration, $0=$ migrant lived with no family or friends at his first migration

1 = migrant found $\mathrm{a}$ job within 1 month at first migration, $0=$ migrant did not find a job in 1 month

Years of formal schooling completed

Percentage of neighbour coming from Isan for migrants in 2000 . First refers to first migration and now to the year 2000 
Table 2. Descriptive Statistics

\begin{tabular}{|c|c|c|c|c|c|c|c|c|}
\hline & & Nang Rong & All migrants & Bangkok & Khorat E & eabord & Buriram & Others \\
\hline \multirow[t]{2}{*}{ Age in $2000^{*}$} & \multirow[t]{2}{*}{ mean } & 25.62 & 26.21 & 25.97 & 27.71 & 24.88 & 26.78 & 26.42 \\
\hline & & 5,21 & 4.55 & 4.30 & 5.71 & 4.58 & 5.32 & 4.54 \\
\hline \multirow[t]{2}{*}{ Male* } & mean & 0.54 & 0.49 & 0.47 & 0.60 & 0.52 & 0.52 & 0.47 \\
\hline & $s d$ & 0.50 & 0.50 & 0.50 & 0.49 & 0.50 & 0.50 & 0.50 \\
\hline \multirow[t]{2}{*}{ Single* } & mean & 0.40 & 0.35 & 0.41 & 0.38 & 0.46 & 0.30 & 0.29 \\
\hline & $s d$ & 0.49 & 0.48 & 0.49 & 0.49 & 0.50 & 0.46 & 0.45 \\
\hline \multirow[t]{2}{*}{ Parental Education* } & mean & 8.79 & 8.88 & 8.80 & 9.18 & 8.92 & 9.74 & 8.75 \\
\hline & $s d$ & 4.03 & 4.05 & 3.88 & 4.02 & 3.98 & 5.31 & 3.78 \\
\hline \multirow[t]{2}{*}{ Education completed* } & mean & 6.33 & 6.39 & 5.79 & 6.67 & 5.13 & 8.48 & 7.02 \\
\hline & $s d$ & 3.37 & 3.72 & 3.29 & 3.74 & 2.59 & 4.01 & 4.23 \\
\hline \multirow[t]{2}{*}{ Asset Score* } & mean & 0.19 & 0.16 & 0.12 & 0.11 & 0.18 & 0.26 & 0.09 \\
\hline & $s d$ & 1.34 & 1.44 & 1.31 & 1.39 & 1.43 & 1.93 & 1.44 \\
\hline \multirow[t]{2}{*}{ Siblings* } & mean & 0.12 & 1.08 & 1.09 & 0.86 & 1.47 & 1.01 & 1.07 \\
\hline & $s d$ & 0.67 & 2.06 & 2.14 & 1.95 & 2.29 & 1.80 & 1.98 \\
\hline \multirow[t]{2}{*}{ Road Length ${ }^{\star \star}$} & mean & 5.65 & 5.27 & 5.47 & 5.58 & 5.79 & 5.58 & 4.95 \\
\hline & $s d$ & 3.30 & 3.11 & 3.23 & 3.08 & 3.21 & 3.10 & 2.96 \\
\hline \multirow[t]{2}{*}{ Network ${ }^{\star \star \star}$} & mean & & 48.39 & 63.31 & 5.86 & 11.86 & 34.13 & 48.51 \\
\hline & $s d$ & & 30.83 & 30.22 & 3.78 & 10.17 & 19.46 & 25.47 \\
\hline \multirow[t]{2}{*}{ 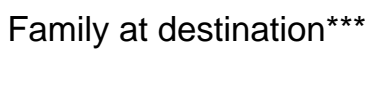 } & mean & & 1.36 & 1.32 & 0.54 & 1.08 & 0.83 & 1.26 \\
\hline & $s d$ & & 1.06 & 1.13 & 0.73 & 1.05 & 0.86 & 1.14 \\
\hline \multirow[t]{2}{*}{ Return*** } & mean & & 4.51 & 5.29 & 3.22 & 2.82 & 3.49 & 4.65 \\
\hline & $s d$ & & 7.16 & 7.60 & 6.42 & 5.78 & 6.94 & 7.00 \\
\hline \multirow[t]{2}{*}{ Salary** } & mean & & 12.53 & 12.07 & 13.94 & 14.12 & 12.95 & 11.96 \\
\hline & $s d$ & & 12.53 & 11.91 & 8.20 & 9.49 & 10.17 & 14.48 \\
\hline \multirow[t]{2}{*}{ Money received** } & mean & & 3.88 & 3.29 & 3.44 & 4.09 & 4.45 & 4.22 \\
\hline & $s d$ & & 1.89 & 1.59 & 2.40 & 1.74 & 2.02 & 1.99 \\
\hline \multirow{2}{*}{ Money sent** } & mean & & 4.54 & 4.62 & 4.56 & 4.51 & 4.87 & 4.17 \\
\hline & $s d$ & & 1.47 & 1.41 & 1.67 & 1.66 & 1.40 & 1.55 \\
\hline \multirow[t]{2}{*}{ Others came ${ }^{\star \star}$} & mean & & 0.62 & 0.64 & 0.69 & 0.60 & 0.54 & 0.61 \\
\hline & $s d$ & & 0.48 & 0.48 & 0.47 & 0.49 & 0.50 & 0.49 \\
\hline \multirow[t]{2}{*}{ Others living ${ }^{\star \star}$} & mean & & 0.73 & 0.75 & 0.68 & 0.68 & 0.60 & 0.76 \\
\hline & $s d$ & & 0.45 & 0.43 & 0.47 & 0.47 & 0.49 & 0.43 \\
\hline \multirow[t]{2}{*}{ Support** } & mean & & 0.61 & 0.67 & 0.60 & 0.56 & 0.34 & 0.66 \\
\hline & $s d$ & & 0.49 & 0.47 & 0.49 & 0.50 & 0.47 & 0.47 \\
\hline \multirow[t]{2}{*}{ Job in 1 month** } & mean & & 0.88 & 0.88 & 0.69 & 0.88 & 0.93 & 0.76 \\
\hline & $s d$ & & 0.33 & 0.33 & 0.47 & 0.33 & 0.25 & 0.43 \\
\hline \multirow[t]{2}{*}{ Isan Neighbours first** } & mean & & 62.17 & 60.78 & 64.72 & 70.97 & 54.54 & 63.61 \\
\hline & $s d$ & & 30.46 & 31.16 & 26.19 & 28.65 & 31.42 & 29.28 \\
\hline \multirow[t]{2}{*}{ Isan Neighbours now** } & mean & & 60.33 & 60.05 & 64.71 & 56.69 & 58.72 & 60.84 \\
\hline & $s d$ & & 31.73 & 31.92 & 32.00 & 34.14 & 30.62 & 31.34 \\
\hline \multirow[t]{2}{*}{ Isan friends now ${ }^{\star *}$} & mean & & 67.36 & 66.83 & 63.18 & 65.17 & 63.61 & 67.44 \\
\hline & $s d$ & & 39.48 & 40.12 & 41.69 & 38.15 & 42.14 & 38.66 \\
\hline
\end{tabular}

Note: *Statistics refer to individuals retained in the estimation sample, migrants or stayers in Nang Rong during the 2000 survey (those for which life histories for the age 13-25 are not missing).

** Statistics refer to pooled data from the Nang Rong migrant follow-up data in 1994 and 2000 surveys.

*** Statistics are authors' computations using pooled life history data from both the 2000 Nang Rong resident and the 2000 migrant follow up surveys. See definitions in table 1 for details on computations. 
Table 3. Transition Matrix for joint mobility and study choices (13-25 years old / all cohorts)

\begin{tabular}{|c|c|c|c|c|}
\hline & Stay and Work & Stay and Study & Migrate and Work & Migrate and Study \\
\hline Stay and Work & $\begin{array}{l}23,474 \\
(48.57)\end{array}$ & $\begin{array}{l}75 \\
(0.16)\end{array}$ & $\begin{array}{l}2,117 \\
(4.38)\end{array}$ & $\begin{array}{l}22 \\
(0.05)\end{array}$ \\
\hline Stay and Study & $\begin{array}{l}414 \\
(0.86)\end{array}$ & $\begin{array}{l}3,741 \\
(7.74)\end{array}$ & $\begin{array}{l}283 \\
(0.59)\end{array}$ & $\begin{array}{l}189 \\
(0.39)\end{array}$ \\
\hline Migrate and Work & $\begin{array}{l}1,662 \\
(3.44)\end{array}$ & $\begin{array}{l}30 \\
(0.06)\end{array}$ & $\begin{array}{l}14,583 \\
(30.17)\end{array}$ & $\begin{array}{l}64 \\
(0.13)\end{array}$ \\
\hline Migrate and Study & $\begin{array}{l}76 \\
(0.16)\end{array}$ & $\begin{array}{l}23 \\
(0.05)\end{array}$ & $\begin{array}{l}241 \\
(0.5)\end{array}$ & $\begin{array}{c}1,335 \\
(2.76)\end{array}$ \\
\hline
\end{tabular}

Note: Author's calculations on sample extracted from Nang Rong life history data for 2000; the numbers on the diagonal indicate the cases of no changes in status from one year to the following in the panel. Outside the diagonal are the cases of transitions from the state indicated in the first column at one year, to the state indicated in the first line at the following year (for example, in our sample there have been 414 cases of transitions from the state of residence in Nang Rong as a student (Stay and Study) to the state of residence in Nang Rong as a worker (Stay and Work)). In parenthesis percentages over all states observed are displayed. 


\begin{tabular}{|c|c|c|c|c|c|c|c|}
\hline \multirow[b]{2}{*}{ Dependent variable } & \multirow{2}{*}{$\begin{array}{l}\text { Probit } \\
(1) \\
\text { Student }\end{array}$} & \multirow{2}{*}{$\begin{array}{c}\text { Probit with FE } \\
\text { (2) } \\
\text { Student } \\
\end{array}$} & \multicolumn{2}{|c|}{$\begin{array}{l}\text { Probit selection } \\
\text { (3) }\end{array}$} & \multicolumn{2}{|c|}{$\begin{array}{l}\text { Probit selection with FE } \\
\text { (4) }\end{array}$} & \multirow{2}{*}{$\begin{array}{c}\text { Semi- } \\
\text { parametric } \\
(5) \\
\text { Student }\end{array}$} \\
\hline & & & Student & Migrant & Student & Migrant & \\
\hline Network Size/10 & $\begin{array}{l}-0.05 b \\
{[0.02]}\end{array}$ & $\begin{array}{l}-0.07 a \\
{[0.03]}\end{array}$ & $\begin{array}{l}-0.04 c \\
{[0.03]}\end{array}$ & & $\begin{array}{l}-0.07 a \\
{[0.02]}\end{array}$ & & $\begin{array}{l}-0.08 a \\
{[0.03]}\end{array}$ \\
\hline Total network & & & & $\begin{array}{l}1.29 a \\
{[0.16]}\end{array}$ & & $\begin{array}{l}1.93 a \\
{[0.20]}\end{array}$ & \\
\hline Family migration & & & & $\begin{array}{l}1.01 a \\
{[0.20]}\end{array}$ & & $\begin{array}{l}0.95 a \\
{[0.20]}\end{array}$ & \\
\hline Rain volume (family) & & & & $\begin{array}{c}-0.91 a \\
{[0.33]}\end{array}$ & & $\begin{array}{c}-1.07 a \\
{[0.28]}\end{array}$ & \\
\hline Road Lenght & & & & $\begin{array}{c}-0.04 a \\
{[0.01]}\end{array}$ & & & \\
\hline Age in 2000 & $\begin{array}{c}0.02 \\
{[0.04]}\end{array}$ & $\begin{array}{c}0.02 \\
{[0.05]}\end{array}$ & $\begin{array}{c}0.01 \\
{[0.08]}\end{array}$ & $\begin{array}{l}-0.01 \\
{[0.04]}\end{array}$ & $\begin{array}{l}0.001 \\
{[0.08]}\end{array}$ & $\begin{array}{l}0.001 \\
{[0.04]}\end{array}$ & $\begin{array}{c}0.1 \\
{[0.11]}\end{array}$ \\
\hline Male & $\begin{array}{c}0.02 \\
{[0.16]}\end{array}$ & $\begin{array}{c}0.02 \\
{[0.16]}\end{array}$ & $\begin{array}{c}0.01 \\
{[0.16]}\end{array}$ & $\begin{array}{l}-0.07 \\
{[0.07]}\end{array}$ & $\begin{array}{c}0.04 \\
{[0.15]}\end{array}$ & $\begin{array}{l}-0.09 \\
{[0.07]}\end{array}$ & $\begin{array}{c}0.07 \\
{[0.17]}\end{array}$ \\
\hline Single & $\begin{array}{l}0.68 a \\
{[0.16]}\end{array}$ & $\begin{array}{l}0.80 a \\
{[0.17]}\end{array}$ & $\begin{array}{l}0.63 b \\
{[0.25]}\end{array}$ & $\begin{array}{c}-0.27 a \\
{[0.07]}\end{array}$ & $\begin{array}{l}0.82 \mathrm{a} \\
{[0.16]}\end{array}$ & $\begin{array}{c}-0.28 a \\
{[0.07]}\end{array}$ & $\begin{array}{l}0.88 a \\
{[0.18]}\end{array}$ \\
\hline Parental education & $\begin{array}{l}0.18 a \\
{[0.03]}\end{array}$ & $\begin{array}{l}0.21 \mathrm{a} \\
{[0.03]}\end{array}$ & $\begin{array}{l}0.18 a \\
{[0.04]}\end{array}$ & $\begin{array}{l}-0.02 \mathrm{c} \\
{[0.01]}\end{array}$ & $\begin{array}{l}0.20 \mathrm{a} \\
{[0.03]}\end{array}$ & $\begin{array}{l}-0.01 \\
{[0.01]}\end{array}$ & $\begin{array}{l}0.21 \mathrm{a} \\
{[0.03]}\end{array}$ \\
\hline Siblings & $\begin{array}{c}0.01 \\
{[0.03]}\end{array}$ & $\begin{array}{c}0.01 \\
{[0.03]}\end{array}$ & $\begin{array}{c}0.02 \\
{[0.04]}\end{array}$ & $\begin{array}{l}0.08 \mathrm{a} \\
{[0.02]}\end{array}$ & $\begin{array}{l}-0.01 \\
{[0.03]}\end{array}$ & $\begin{array}{l}0.08 \mathrm{a} \\
{[0.02]}\end{array}$ & $\begin{array}{l}-0.02 \\
{[0.09]}\end{array}$ \\
\hline Language & $\begin{array}{l}-0.04 \\
{[0.20]}\end{array}$ & $\begin{array}{l}-0.15 \\
{[0.23]}\end{array}$ & $\begin{array}{l}-0.01 \\
{[0.22]}\end{array}$ & $\begin{array}{l}0.24 a \\
{[0.08]}\end{array}$ & $\begin{array}{l}-0.19 \\
{[0.22]}\end{array}$ & $\begin{array}{l}0.15 c \\
{[0.09]}\end{array}$ & $\begin{array}{l}-0.38 \\
{[0.27]}\end{array}$ \\
\hline Asset score & $\begin{array}{l}0.18 a \\
{[0.05]}\end{array}$ & $\begin{array}{l}0.19^{\circ} \\
{[0.06]}\end{array}$ & $\begin{array}{l}0.18 \mathrm{a} \\
{[0.06]}\end{array}$ & $\begin{array}{l}-0.04 \\
{[0.03]}\end{array}$ & $\begin{array}{l}0.19 a \\
{[0.05]}\end{array}$ & $\begin{array}{l}-0.04 \\
{[0.03]}\end{array}$ & $\begin{array}{l}0.25 a \\
{[0.06]}\end{array}$ \\
\hline School & $\begin{array}{l}-0.09 \\
{[0.20]}\end{array}$ & $\begin{array}{l}-0.49 \\
{[0.42]}\end{array}$ & $\begin{array}{l}-0.09 \\
{[0.20]}\end{array}$ & & $\begin{array}{l}-0.47 \\
{[0.39]}\end{array}$ & & $\begin{array}{l}-0.59 \\
{[0.42]}\end{array}$ \\
\hline Eastern Seaboard & $\begin{array}{l}-0.32 \\
{[0.31]}\end{array}$ & $\begin{array}{l}-0.41 \\
{[0.35]}\end{array}$ & $\begin{array}{l}-0.29 \\
{[0.32]}\end{array}$ & & $\begin{array}{l}-0.42 \\
{[0.33]}\end{array}$ & & $\begin{array}{l}-0.56 \\
{[0.37]}\end{array}$ \\
\hline Khorat & $\begin{array}{c}0.27 \\
{[0.20]}\end{array}$ & $\begin{array}{c}0.26 \\
{[0.19]}\end{array}$ & $\begin{array}{c}0.28 \\
{[0.20]}\end{array}$ & & $\begin{array}{c}0.22 \\
{[0.18]}\end{array}$ & & $\begin{array}{c}0.27 \\
{[0.21]}\end{array}$ \\
\hline Buriram & $\begin{array}{l}1.11 \mathrm{a} \\
{[0.22]}\end{array}$ & $\begin{array}{l}1.16 \mathrm{a} \\
{[0.21]}\end{array}$ & $\begin{array}{l}1.11 \mathrm{a} \\
{[0.22]}\end{array}$ & & $\begin{array}{l}1.05 a \\
{[0.21]}\end{array}$ & & $\begin{array}{l}1.19 a \\
{[0.22]}\end{array}$ \\
\hline $\operatorname{Pr}$ (out) & & & & & & & $\begin{array}{c}23.83 b \\
{[9.42]}\end{array}$ \\
\hline $\operatorname{Pr}(\text { out })^{2}$ & & & & & & & $\begin{array}{l}-45.65 \\
{[29.89]}\end{array}$ \\
\hline $\operatorname{Pr}(\text { out })^{3}$ & & & & & & & $\begin{array}{c}43.47 \\
{[41.41]}\end{array}$ \\
\hline $\operatorname{Pr}(\text { out })^{4}$ & & & & & & & $\begin{array}{l}-18.22 \\
{[20.58]}\end{array}$ \\
\hline Time fixed effects & Yes & Yes & Yes & Yes & Yes & Yes & Yes \\
\hline Age fixed effects & Yes & Yes & Yes & Yes & Yes & Yes & Yes \\
\hline Village fixed effects & No & Yes & No & No & Yes & Yes & Yes \\
\hline $\begin{array}{l}\text { Constant } \\
\text { Observations }\end{array}$ & $\begin{array}{l}-3.33 b \\
{[1.46]} \\
2164\end{array}$ & $\begin{array}{l}-4.27 a \\
{[1.60]} \\
2089\end{array}$ & $\begin{array}{l}-3.32 \\
{[2.86]} \\
2164\end{array}$ & $\begin{array}{l}-0.62 \\
{[1.40]} \\
5961\end{array}$ & $\begin{array}{l}-2.83 \\
{[2.86]} \\
2164\end{array}$ & $\begin{array}{l}-1.05 \\
{[1.47]} \\
5961\end{array}$ & $\begin{array}{c}-10.30 \mathrm{~b} \\
{[4.38]} \\
2084\end{array}$ \\
\hline Log Pseudolikelihood & -461.62 & -417.36 & & .44 & & & -396.36 \\
\hline
\end{tabular}

Robust standard errors in brackets, corrected for intra-cluster correlation at the individual level c significant at $10 \%$; b significant at $5 \%$; a significant at $1 \%$.

Note: In column 3 and 4 the bivariate probit model is estimated by full maximum likelihood, using the heckprob command in STATA. Semi-parametric in column 5 refers to the estimation method suggested in Newey et al.(1990), and use a quartic in the predicted probability of migration estimated as a first stage. 
Table 5. IV and Three-Stage Estimation of network effects on schooling enrolment

\begin{tabular}{|c|c|c|c|c|c|c|c|c|}
\hline \multirow[b]{2}{*}{ Dependent variable } & \multicolumn{2}{|c|}{$\begin{array}{l}\text { IV Probit } \\
\text { (1) }\end{array}$} & \multicolumn{2}{|c|}{$\begin{array}{l}\text { IV Probit } \\
\text { (2) }\end{array}$} & \multicolumn{2}{|c|}{$\begin{array}{l}2 S L S \\
(3)\end{array}$} & \multicolumn{2}{|c|}{$\begin{array}{l}\text { 2SLS with selection } \\
\text { (4) }\end{array}$} \\
\hline & Student & Network & Student & Network & Student & Network & Student & Network \\
\hline Network size/10 & $\begin{array}{c}-0.15 a \\
{[0.05]}\end{array}$ & & $\begin{array}{c}-0.17 a \\
{[0.06]}\end{array}$ & & $\begin{array}{l}-0.02 \mathrm{c} \\
{[0.01]}\end{array}$ & & $\begin{array}{l}-0.02 c \\
{[0.01]}\end{array}$ & \\
\hline Military & & $\begin{array}{l}0.36 \mathrm{a} \\
{[0.05]}\end{array}$ & & $\begin{array}{l}0.14 a \\
{[0.05]}\end{array}$ & & $\begin{array}{l}0.14 a \\
{[0.04]}\end{array}$ & & $\begin{array}{l}0.14 \mathrm{a} \\
{[0.04]}\end{array}$ \\
\hline Rain volume (village) & & $\begin{array}{l}-4.04 a \\
{[1.43]}\end{array}$ & & & & & & \\
\hline Return & & $\begin{array}{l}0.11 \mathrm{a} \\
{[0.01]}\end{array}$ & & $\begin{array}{l}0.09 a \\
{[0.01]}\end{array}$ & & $\begin{array}{l}0.09 a \\
{[0.01]}\end{array}$ & & $\begin{array}{l}0.09 a \\
{[0.01]}\end{array}$ \\
\hline Selection (IMR) & & & & & & & $\begin{array}{l}-0.29 a \\
{[0.09]}\end{array}$ & $\begin{array}{l}-1.46 a \\
{[0.44]}\end{array}$ \\
\hline Road Lenght & & $\begin{array}{l}-0.08 \mathrm{a} \\
{[0.03]}\end{array}$ & & & & & & \\
\hline Age in 2000 & $\begin{array}{c}0.01 \\
{[0.07]}\end{array}$ & $\begin{array}{l}0.001 \\
{[0.06]}\end{array}$ & $\begin{array}{c}0.01 \\
{[0.07]}\end{array}$ & $\begin{array}{c}0.08 \\
{[0.07]}\end{array}$ & $\begin{array}{l}0.001 \\
{[0.01]}\end{array}$ & $\begin{array}{c}0.08 \\
{[0.06]}\end{array}$ & $\begin{array}{c}0.02 \\
{[0.01]}\end{array}$ & $\begin{array}{c}0.15 \\
{[0.06]}\end{array}$ \\
\hline Male & $\begin{array}{c}0.03 \\
{[0.15]}\end{array}$ & $\begin{array}{c}0.14 \\
{[0.19]}\end{array}$ & $\begin{array}{c}0.02 \\
{[0.15]}\end{array}$ & $\begin{array}{c}0.04 \\
{[0.16]}\end{array}$ & $\begin{array}{l}0.001 \\
{[0.02]}\end{array}$ & $\begin{array}{c}0.06 \\
{[0.10]}\end{array}$ & $\begin{array}{c}0.01 \\
{[0.02]}\end{array}$ & $\begin{array}{c}0.11 \\
{[0.10]}\end{array}$ \\
\hline Single & $\begin{array}{l}0.64 a \\
{[0.16]}\end{array}$ & $\begin{array}{l}-0.16 \\
{[0.20]}\end{array}$ & $\begin{array}{l}-0.11 \\
{[0.16]}\end{array}$ & $\begin{array}{l}0.76 \mathrm{a} \\
{[0.16]}\end{array}$ & $\begin{array}{l}0.08 \mathrm{a} \\
{[0.02]}\end{array}$ & $\begin{array}{c}-0.1 \\
{[0.11]}\end{array}$ & $\begin{array}{l}0.10 \mathrm{a} \\
{[0.02]}\end{array}$ & $\begin{array}{c}0.02 \\
{[0.11]}\end{array}$ \\
\hline Parental education & $\begin{array}{l}0.18 a \\
{[0.03]}\end{array}$ & $\begin{array}{l}-0.01 \\
{[0.03]}\end{array}$ & $\begin{array}{l}-0.01 \\
{[0.03]}\end{array}$ & $\begin{array}{l}0.20 \mathrm{a} \\
{[0.03]}\end{array}$ & $\begin{array}{l}0.03 a \\
{[0.00]}\end{array}$ & $\begin{array}{c}0 \\
{[0.01]}\end{array}$ & $\begin{array}{l}0.02 \mathrm{a} \\
{[0.00]}\end{array}$ & $\begin{array}{l}-0.01 \\
{[0.01]}\end{array}$ \\
\hline Siblings & $\begin{array}{c}0.01 \\
{[0.03]}\end{array}$ & $\begin{array}{l}0.001 \\
{[0.03]}\end{array}$ & $\begin{array}{c}0.01 \\
{[0.03]}\end{array}$ & $\begin{array}{c}0.02 \\
{[0.03]}\end{array}$ & $\begin{array}{l}0.001 \\
{[0.00]}\end{array}$ & $\begin{array}{c}0.02 \\
{[0.02]}\end{array}$ & $\begin{array}{c}-0.02 a \\
{[0.01]}\end{array}$ & $\begin{array}{l}-0.08 b \\
{[0.04]}\end{array}$ \\
\hline Language & $\begin{array}{l}-0.05 \\
{[0.20]}\end{array}$ & $\begin{array}{c}0.23 \\
{[0.25]}\end{array}$ & $\begin{array}{l}-0.18 \\
{[0.23]}\end{array}$ & $\begin{array}{l}-0.24 \\
{[0.23]}\end{array}$ & $\begin{array}{l}-0.04 \\
{[0.02]}\end{array}$ & $\begin{array}{l}-0.26 \mathrm{c} \\
{[0.13]}\end{array}$ & $\begin{array}{l}-0.06 b \\
{[0.03]}\end{array}$ & $\begin{array}{l}-0.41 b \\
{[0.14]}\end{array}$ \\
\hline Asset score & $\begin{array}{l}0.18 a \\
{[0.05]}\end{array}$ & $\begin{array}{c}0.02 \\
{[0.09]}\end{array}$ & $\begin{array}{l}-0.12 \\
{[0.08]}\end{array}$ & $\begin{array}{l}0.17 a \\
{[0.05]}\end{array}$ & $\begin{array}{l}0.04 a \\
{[0.01]}\end{array}$ & $\begin{array}{l}-0.11 \mathrm{a} \\
{[0.04]}\end{array}$ & $\begin{array}{l}0.05 a \\
{[0.01]}\end{array}$ & $\begin{array}{l}-0.07 \mathrm{c} \\
{[0.04]}\end{array}$ \\
\hline School & $\begin{array}{l}-0.13 \\
{[0.20]}\end{array}$ & $\begin{array}{c}-0.1 \\
{[0.31]}\end{array}$ & $\begin{array}{l}-0.53 \\
{[0.40]}\end{array}$ & $\begin{array}{l}-0.54 \\
{[0.64]}\end{array}$ & $\begin{array}{l}-0.06 \\
{[0.07]}\end{array}$ & $\begin{array}{l}-0.54 \mathrm{C} \\
{[0.30]}\end{array}$ & $\begin{array}{l}-0.07 \\
{[0.07]}\end{array}$ & $\begin{array}{l}-0.57 \mathrm{c} \\
{[0.30]}\end{array}$ \\
\hline Eastern Seaboard & $\begin{array}{l}-0.74 b \\
{[0.34]}\end{array}$ & $\begin{array}{l}-4.37 a \\
{[0.22]}\end{array}$ & $\begin{array}{l}-0.81 b \\
{[0.40]}\end{array}$ & $\begin{array}{l}-3.94 a \\
{[0.24]}\end{array}$ & $\begin{array}{l}-0.08 \mathrm{c} \\
{[0.05]}\end{array}$ & $\begin{array}{l}-3.98 \mathrm{a} \\
{[0.17]}\end{array}$ & $\begin{array}{l}-0.10 c \\
{[0.05]}\end{array}$ & $\begin{array}{l}-4.00 \mathrm{a} \\
{[0.17]}\end{array}$ \\
\hline Khorat & $\begin{array}{c}0.04 \\
{[0.20]}\end{array}$ & $\begin{array}{l}-2.23 a \\
{[0.23]}\end{array}$ & $\begin{array}{c}0.03 \\
{[0.22]}\end{array}$ & $\begin{array}{l}-2.07 a \\
{[0.19]}\end{array}$ & $\begin{array}{l}0.01 \\
{[0.03]}\end{array}$ & $\begin{array}{l}-2.09 a \\
{[0.11]}\end{array}$ & $\begin{array}{c}0.01 \\
{[0.03]}\end{array}$ & $\begin{array}{l}-2.09 a \\
{[0.11]}\end{array}$ \\
\hline Buriram & $\begin{array}{l}0.76 a \\
{[0.26]}\end{array}$ & $\begin{array}{l}-3.18 \mathrm{a} \\
{[0.27]}\end{array}$ & $\begin{array}{l}-2.82 a \\
{[0.30]}\end{array}$ & $\begin{array}{l}0.83 a \\
{[0.29]}\end{array}$ & $\begin{array}{l}0.23 a \\
{[0.05]}\end{array}$ & $\begin{array}{l}-2.83 a \\
{[0.16]}\end{array}$ & $\begin{array}{l}0.23 a \\
{[0.05]}\end{array}$ & $\begin{array}{l}-2.85 a \\
{[0.11]}\end{array}$ \\
\hline Time fixed effects & Yes & Yes & Yes & Yes & Yes & Yes & Yes & Yes \\
\hline Age fixed effects & Yes & Yes & Yes & Yes & Yes & Yes & Yes & Yes \\
\hline Village fixed effects & No & No & Yes & Yes & Yes & Yes & Yes & Yes \\
\hline Constant & $\begin{array}{l}-2.42 \\
{[2.93]}\end{array}$ & $\begin{array}{l}4.94 b \\
{[2.41]}\end{array}$ & $\begin{array}{l}-3.09 \\
{[2.86]}\end{array}$ & $\begin{array}{c}2.9 \\
{[0.15]}\end{array}$ & $\begin{array}{l}0.002 \\
{[0.36]}\end{array}$ & $\begin{array}{c}2.8 \\
{[2.17]}\end{array}$ & $\begin{array}{l}-0.14 \\
{[0.34]}\end{array}$ & $\begin{array}{c}2.02 \\
{[2.18]}\end{array}$ \\
\hline \multirow[t]{2}{*}{$\begin{array}{l}\text { Observations } \\
\text { Log Pseudolikelihood } \\
\text { R squared }\end{array}$} & \multicolumn{2}{|c|}{$\begin{array}{l}2164 \\
-5550.18\end{array}$} & \multirow{2}{*}{\multicolumn{2}{|c|}{$\begin{array}{c}2089 \\
-4934.51\end{array}$}} & \multicolumn{2}{|c|}{2164} & \multicolumn{2}{|c|}{2164} \\
\hline & & & & & 0.36 & 0.55 & 0.37 & 0.56 \\
\hline
\end{tabular}

Robust standard errors in bracket, corrected for intra-cluster correlation at the individual level

c significant at $10 \%$; b significant at $5 \%$; a significant at $1 \%$

Note: The estimation method in column (1) and (2) is the Newey (1987) Amemiya (1978) instrumental variable probit. In column (3) and (4) the model is estimated through two stage least squares; in column (4) the inverse mills ratio computed from a probit estimation of the migration model (see column 2, table 5), is included following Mroz (1987). 


\begin{tabular}{|c|c|c|c|c|c|c|}
\hline \multirow[b]{2}{*}{ Dependent variable } & \multicolumn{2}{|c|}{$\begin{array}{l}2 S L S \text { with selection } \\
\text { (1) }\end{array}$} & \multicolumn{2}{|c|}{$\begin{array}{l}2 S L S \text { with selection } \\
\text { (2) }\end{array}$} & \multicolumn{2}{|c|}{$\begin{array}{l}\text { 2SLS with selection } \\
\text { (3) }\end{array}$} \\
\hline & student & network & student & network & student & network \\
\hline Network size/10 & $\begin{array}{c}-0.01 b \\
{[0.01]}\end{array}$ & & $\begin{array}{l}-0.02 c \\
{[0.01]}\end{array}$ & & $\begin{array}{l}-0.02 \mathrm{~b} \\
{[0.01]}\end{array}$ & \\
\hline Military & & $\begin{array}{l}0.11 \mathrm{a} \\
{[0.02]}\end{array}$ & & $\begin{array}{l}0.09 b \\
{[0.04]}\end{array}$ & & $\begin{array}{l}0.14 a \\
{[0.04]}\end{array}$ \\
\hline $\begin{array}{l}\text { Rain volume } \\
\text { (village) }\end{array}$ & & & & & & \\
\hline Return & & $\begin{array}{l}{[0.80]} \\
0.10 \mathrm{a} \\
{[0.00]}\end{array}$ & & $\begin{array}{l}{[1.38]} \\
0.06^{\circ} \\
{[0.01]}\end{array}$ & & $\begin{array}{l}{[1.39]} \\
0.09 a \\
{[0.01]}\end{array}$ \\
\hline Selection (IMR) & $\begin{array}{r}-0.12 b \\
{[0.06]}\end{array}$ & $\begin{array}{l}-1.57 \mathrm{a} \\
{[0.27]}\end{array}$ & $\begin{array}{l}-0.28 a \\
{[0.09]}\end{array}$ & $\begin{array}{c}-0.93 b \\
{[0.45]}\end{array}$ & $\begin{array}{l}-0.14 c \\
{[0.08]}\end{array}$ & $\begin{array}{l}-1.35 a \\
{[0.46]}\end{array}$ \\
\hline Age in 2000 & $\begin{array}{l}0.01 \mathrm{c} \\
{[0.01]}\end{array}$ & $\begin{array}{l}0.15 a \\
{[0.03]}\end{array}$ & $\begin{array}{l}0.02 \mathrm{c} \\
{[0.01]}\end{array}$ & $\begin{array}{l}0.15 b \\
{[0.06]}\end{array}$ & $\begin{array}{c}0.01 \\
{[0.01]}\end{array}$ & $\begin{array}{c}0.11 \\
{[0.07]}\end{array}$ \\
\hline Male & $\begin{array}{c}0.01 \\
{[0.01]}\end{array}$ & $\begin{array}{c}0.06 \\
{[0.06]}\end{array}$ & $\begin{array}{c}0.02 \\
{[0.02]}\end{array}$ & $\begin{array}{c}0.13 \\
{[0.10]}\end{array}$ & $\begin{array}{l}-0.01 \\
{[0.02]}\end{array}$ & $\begin{array}{c}0.08 \\
{[0.10]}\end{array}$ \\
\hline Single & $\begin{array}{l}0.08 \mathrm{a} \\
{[0.01]}\end{array}$ & $\begin{array}{l}-0.02 \\
{[0.07]}\end{array}$ & $\begin{array}{l}0.10 \mathrm{a} \\
{[0.02]}\end{array}$ & $\begin{array}{l}0.001 \\
{[0.12]}\end{array}$ & $\begin{array}{l}0.05 a \\
{[0.02]}\end{array}$ & $\begin{array}{l}-0.01 \\
{[0.12]}\end{array}$ \\
\hline Parental education & $\begin{array}{l}0.01 \mathrm{a} \\
{[0.00]}\end{array}$ & $\begin{array}{l}-0.03 a \\
{[0.01]}\end{array}$ & $\begin{array}{l}0.02 \mathrm{a} \\
{[0.00]}\end{array}$ & $\begin{array}{l}-0.01 \\
{[0.02]}\end{array}$ & $\begin{array}{l}0.02 \mathrm{a} \\
{[0.00]}\end{array}$ & $\begin{array}{l}-0.02 \\
{[0.02]}\end{array}$ \\
\hline Siblings & $\begin{array}{c}0.001 \\
{[0.001]}\end{array}$ & $\begin{array}{l}-0.07 a \\
{[0.02]}\end{array}$ & $\begin{array}{l}-0.01 b \\
{[0.01]}\end{array}$ & $\begin{array}{l}-0.06 c \\
{[0.04]}\end{array}$ & $\begin{array}{l}-0.01 \mathrm{c} \\
{[0.01]}\end{array}$ & $\begin{array}{l}-0.08 b \\
{[0.04]}\end{array}$ \\
\hline Language & $\begin{array}{l}-0.01 \\
{[0.02]}\end{array}$ & $\begin{array}{l}-0.16 \mathrm{c} \\
{[0.08]}\end{array}$ & $\begin{array}{l}-0.07 \mathrm{~b} \\
{[0.03]}\end{array}$ & $\begin{array}{l}-0.33 b \\
{[0.15]}\end{array}$ & $\begin{array}{l}-0.04 \\
{[0.02]}\end{array}$ & $\begin{array}{l}-0.37 \mathrm{~b} \\
{[0.15]}\end{array}$ \\
\hline Asset score & $\begin{array}{l}0.03 a \\
{[0.01]}\end{array}$ & $\begin{array}{l}-0.05 b \\
{[0.02]}\end{array}$ & $\begin{array}{l}0.05 a \\
{[0.01]}\end{array}$ & $\begin{array}{l}-0.09 b \\
{[0.04]}\end{array}$ & $\begin{array}{l}0.04 a \\
{[0.01]}\end{array}$ & $\begin{array}{l}-0.01 \\
{[0.04]}\end{array}$ \\
\hline School & $\begin{array}{c}0.02 \\
{[0.04]}\end{array}$ & $\begin{array}{l}-0.14 \\
{[0.17]}\end{array}$ & $\begin{array}{l}-0.07 \\
{[0.07]}\end{array}$ & $\begin{array}{l}-0.56 c \\
{[0.29]}\end{array}$ & $\begin{array}{l}-0.02 \\
{[0.07]}\end{array}$ & $\begin{array}{l}-0.81 b \\
{[0.31]}\end{array}$ \\
\hline Eastern Seaboard & $\begin{array}{c}-0.06 \mathrm{~b} \\
{[0.03]}\end{array}$ & $\begin{array}{l}-3.99 a \\
{[0.10]}\end{array}$ & $\begin{array}{l}-0.11 \mathrm{c} \\
{[0.06]}\end{array}$ & $\begin{array}{l}-3.85 a \\
{[0.17]}\end{array}$ & $\begin{array}{l}-0.12 b \\
{[0.05]}\end{array}$ & $\begin{array}{l}-3.89 a \\
{[0.17]}\end{array}$ \\
\hline Khorat & $\begin{array}{c}0.02 \\
{[0.02]}\end{array}$ & $\begin{array}{l}-1.93 a \\
{[0.07]}\end{array}$ & $\begin{array}{l}-0.01 \\
{[0.04]}\end{array}$ & $\begin{array}{l}-2.00 a \\
{[0.11]}\end{array}$ & $\begin{array}{l}-0.01 \\
{[0.03]}\end{array}$ & $\begin{array}{l}-2.07 a \\
{[0.11]}\end{array}$ \\
\hline Buriram & $\begin{array}{l}0.15 a \\
{[0.03]}\end{array}$ & $\begin{array}{l}-2.54 a \\
{[0.09]}\end{array}$ & $\begin{array}{l}0.23 a \\
{[0.06]}\end{array}$ & $\begin{array}{l}-2.98 a \\
{[0.17]}\end{array}$ & & \\
\hline Average wages & & & $\begin{array}{l}-0.001 \mathrm{~b} \\
{[0.0007]}\end{array}$ & $\begin{array}{l}0.001 \\
{[0.01]}\end{array}$ & & \\
\hline Network education & & & $\begin{array}{l}-0.001 \\
{[0.002]}\end{array}$ & $\begin{array}{l}-0.15 a \\
{[0.01]}\end{array}$ & & \\
\hline Time fixed effects & Yes & Yes & Yes & Yes & Yes & Yes \\
\hline Age fixed effects & Yes & Yes & Yes & Yes & Yes & Yes \\
\hline Village fixed effects & Yes & Yes & Yes & Yes & Yes & Yes \\
\hline Constant & $\begin{array}{l}-0.08 \\
{[0.21]}\end{array}$ & $\begin{array}{c}1.73 \\
{[1.29]}\end{array}$ & $\begin{array}{c}3.03 \\
{[0.39]}\end{array}$ & $\begin{array}{c}3.03 \\
{[2.28]}\end{array}$ & $\begin{array}{l}-0.08 \\
{[0.31]}\end{array}$ & $\begin{array}{l}4.16 \mathrm{c} \\
{[2.42]}\end{array}$ \\
\hline $\begin{array}{l}\text { Observations } \\
\text { R squared }\end{array}$ & 5603 & & 1914 & & 1892 & \\
\hline
\end{tabular}

Robust standard errors in brackets corrected for intra-cluster correlation at the individual level c significant at $10 \%$; b significant at $5 \%$; a significant at $1 \%$.

Note: the model is estimated through two stage least squares; the inverse mills ratio computed from a probit estimation of the migration model (see column 2, table 5), is included following Mroz (1987). 
Table 7. Multinomial mixed logit models for migration and schooling status

\begin{tabular}{|c|c|c|c|c|c|c|c|c|c|c|c|c|}
\hline \multirow[b]{2}{*}{ Dependent variable } & \multicolumn{3}{|c|}{ Mixed Logit (1) } & \multicolumn{3}{|c|}{ Mixed Logit (2) } & \multicolumn{3}{|c|}{ Mixed Logit (3) } & \multicolumn{3}{|c|}{ Mixed Logit (4) } \\
\hline & $\begin{array}{l}\text { Stay and } \\
\text { Study }\end{array}$ & $\begin{array}{c}\text { Migrate and } \\
\text { Study }\end{array}$ & $\begin{array}{l}\text { Migrate and } \\
\text { Work }\end{array}$ & $\begin{array}{l}\text { Stay and } \\
\text { Study }\end{array}$ & $\begin{array}{l}\text { Migrate and } \\
\text { Study }\end{array}$ & $\begin{array}{l}\text { Migrate and } \\
\text { Work }\end{array}$ & Stay and Study & $\begin{array}{c}\text { Migrate and } \\
\text { Study }\end{array}$ & $\begin{array}{c}\text { Migrate and } \\
\text { Work }\end{array}$ & $\begin{array}{l}\text { Stay and } \\
\text { Study }\end{array}$ & $\begin{array}{l}\text { Migrate and } \\
\text { Study }\end{array}$ & $\begin{array}{c}\text { Migrate and } \\
\text { Work }\end{array}$ \\
\hline Network Size & $\begin{array}{r}-0.03 a \\
{[0.01]}\end{array}$ & $\begin{array}{l}-0.01 b \\
{[0.01]}\end{array}$ & $\begin{array}{l}0.01 a \\
{[0.00]}\end{array}$ & $\begin{array}{r}-0.03 a \\
{[0.01]}\end{array}$ & $\begin{array}{l}-0.01 c \\
{[0.01]}\end{array}$ & $\begin{array}{l}0.01 a \\
{[0.00]}\end{array}$ & $\begin{array}{r}-0.03 a \\
{[0.01]}\end{array}$ & $\begin{array}{l}-0.01 c \\
{[0.01]}\end{array}$ & $\begin{array}{l}0.01 a \\
{[0.00]}\end{array}$ & $\begin{array}{r}-0.03 a \\
{[0.01]}\end{array}$ & $\begin{array}{l}-0.01 b \\
{[0.01]}\end{array}$ & $\begin{array}{l}0.01 a \\
{[0.00]}\end{array}$ \\
\hline Male & $\begin{array}{r}0.03 \\
{[0.63]}\end{array}$ & $\begin{array}{l}-0.71 \\
{[0.68]}\end{array}$ & $\begin{array}{l}-0.11 \\
{[0.24]}\end{array}$ & $\begin{array}{r}0.09 \\
{[0.74]}\end{array}$ & $\begin{array}{c}-0.1 \\
{[0.53]}\end{array}$ & $\begin{array}{l}-0.27 \\
{[0.35]}\end{array}$ & $\begin{array}{r}-0.45 \\
{[1.45]}\end{array}$ & $\begin{array}{l}-0.35 \\
{[0.50]}\end{array}$ & $\begin{array}{l}-0.24 \\
{[0.21]}\end{array}$ & $\begin{array}{r}0.57 \\
{[0.48]}\end{array}$ & $\begin{array}{l}0.80 c \\
{[0.45]}\end{array}$ & $\begin{array}{l}-0.23 \\
{[0.20]}\end{array}$ \\
\hline Age in 2000 & $\begin{array}{r}0.07 \\
{[0.55]}\end{array}$ & $\begin{array}{c}-0.3 \\
{[0.19]}\end{array}$ & $\begin{array}{l}0.24 a \\
{[0.07]}\end{array}$ & $\begin{array}{r}0.14 \\
{[0.20]}\end{array}$ & $\begin{array}{l}-0.23 \\
{[0.17]}\end{array}$ & $\begin{array}{l}0.24 a \\
{[0.08]}\end{array}$ & $\begin{array}{r}0.04 \\
{[0.15]}\end{array}$ & $\begin{array}{l}-0.24 \\
{[0.20]}\end{array}$ & $\begin{array}{l}0.24 a \\
{[0.07]}\end{array}$ & $\begin{array}{r}-0.04 \\
{[0.03]}\end{array}$ & $\begin{array}{l}-0.05 a \\
{[0.02]}\end{array}$ & $\begin{array}{l}-0.03 a \\
{[0.00]}\end{array}$ \\
\hline Actual Age & $\begin{array}{l}-0.49 \\
{[1.27]}\end{array}$ & $\begin{array}{l}2.06 \mathrm{a} \\
{[0.57]}\end{array}$ & $\begin{array}{l}1.30 \mathrm{a} \\
{[0.17]}\end{array}$ & $\begin{array}{r}-0.8 \\
{[1.00]}\end{array}$ & $\begin{array}{l}1.34 b \\
{[0.54]}\end{array}$ & $\begin{array}{l}1.27 \mathrm{a} \\
{[0.18]}\end{array}$ & $\begin{array}{l}-0.67 \\
{[0.96]}\end{array}$ & $\begin{array}{l}2.01 \mathrm{a} \\
{[0.55]}\end{array}$ & $\begin{array}{l}1.28 \mathrm{a} \\
{[0.17]}\end{array}$ & $\begin{array}{r}0.02 \\
{[0.14]}\end{array}$ & $\begin{array}{l}-0.05 \\
{[0.16]}\end{array}$ & $\begin{array}{l}0.24 a \\
{[0.07]}\end{array}$ \\
\hline Actual Age squared & $\begin{array}{l}-0.04 \\
{[0.03]}\end{array}$ & $\begin{array}{l}-0.06 a \\
{[0.01]}\end{array}$ & $\begin{array}{l}-0.03 a \\
{[0.00]}\end{array}$ & $\begin{array}{l}-0.03 \\
{[0.03]}\end{array}$ & $\begin{array}{l}-0.05 a \\
{[0.01]}\end{array}$ & $\begin{array}{l}-0.03 a \\
{[0.00]}\end{array}$ & $\begin{array}{l}-0.04 \\
{[0.03]}\end{array}$ & $\begin{array}{l}-0.06 a \\
{[0.01]}\end{array}$ & $\begin{array}{l}-0.03 a \\
{[0.00]}\end{array}$ & $\begin{array}{l}0.85 a \\
{[0.09]}\end{array}$ & $\begin{array}{l}0.17 a \\
{[0.03]}\end{array}$ & $\begin{array}{l}0.78 a \\
{[0.08]}\end{array}$ \\
\hline Parental education & $\begin{array}{l}0.81 \mathrm{a} \\
{[0.12]}\end{array}$ & $\begin{array}{l}0.13 a \\
{[0.05]}\end{array}$ & $\begin{array}{l}0.56 \mathrm{a} \\
{[0.12]}\end{array}$ & $\begin{array}{l}0.79 a \\
{[0.12]}\end{array}$ & $\begin{array}{l}0.13 c \\
{[0.08]}\end{array}$ & $\begin{array}{l}0.67 a \\
{[0.13]}\end{array}$ & $\begin{array}{l}0.94 a \\
{[0.09]}\end{array}$ & $\begin{array}{l}0.13 a \\
{[0.03]}\end{array}$ & $\begin{array}{l}0.66 \mathrm{a} \\
{[0.11]}\end{array}$ & $\begin{array}{l}0.76 \mathrm{a} \\
{[0.14]}\end{array}$ & $\begin{array}{l}0.71 \mathrm{a} \\
{[0.10]}\end{array}$ & $\begin{array}{l}0.89 a \\
{[0.12]}\end{array}$ \\
\hline Siblings & $\begin{array}{l}0.61 a \\
{[0.15]}\end{array}$ & $\begin{array}{l}0.66 a \\
{[0.12]}\end{array}$ & $\begin{array}{l}0.76 a \\
{[0.15]}\end{array}$ & $\begin{array}{l}0.74 a \\
{[0.15]}\end{array}$ & $\begin{array}{l}0.74 a \\
{[0.10]}\end{array}$ & $\begin{array}{l}0.88 a \\
{[0.13]}\end{array}$ & $\begin{array}{l}0.81 \mathrm{a} \\
{[0.13]}\end{array}$ & $\begin{array}{l}0.68 \mathrm{a} \\
{[0.10]}\end{array}$ & $\begin{array}{l}0.76 a \\
{[0.13]}\end{array}$ & $\begin{array}{c}-0.45 \\
{[1.03]}\end{array}$ & $\begin{array}{l}1.36 \mathrm{~b} \\
{[0.56]}\end{array}$ & $\begin{array}{l}1.28 \mathrm{a} \\
{[0.18]}\end{array}$ \\
\hline Asset score & $\begin{array}{l}-0.05 \\
{[0.47]}\end{array}$ & $\begin{array}{l}0.22 \mathrm{a} \\
{[0.08]}\end{array}$ & $\begin{array}{l}-0.23 b \\
{[0.11]}\end{array}$ & $\begin{array}{r}0.2 \\
{[0.24]}\end{array}$ & $\begin{array}{l}0.40 \mathrm{~b} \\
{[0.19]}\end{array}$ & $\begin{array}{l}-0.27 \\
{[0.17]}\end{array}$ & $\begin{array}{l}-0.05 \\
{[0.15]}\end{array}$ & $\begin{array}{l}0.19 \mathrm{c} \\
{[0.11]}\end{array}$ & $\begin{array}{l}-0.22 \mathrm{a} \\
{[0.08]}\end{array}$ & $\begin{array}{l}0.26 \mathrm{c} \\
{[0.13]}\end{array}$ & $\begin{array}{l}0.24 a \\
{[0.08]}\end{array}$ & $\begin{array}{l}-0.36 a \\
{[0.09]}\end{array}$ \\
\hline Random intercept & $\begin{array}{r}-3.11 \\
{[13.55]}\end{array}$ & $\begin{array}{c}-16.17 b \\
{[6.78]}\end{array}$ & $\begin{array}{l}-25.27 a \\
{[2.53]}\end{array}$ & $\begin{array}{l}-4.52 \\
{[8.78]}\end{array}$ & $\begin{array}{c}-24.47 a \\
{[3.40]}\end{array}$ & $\begin{array}{l}-14.21 \mathrm{c} \\
{[7.87]}\end{array}$ & $\begin{array}{l}-5.19 \\
{[8.66]}\end{array}$ & $\begin{array}{c}-19.85 a \\
{[6.89]}\end{array}$ & $\begin{array}{l}-23.82 \mathrm{a} \\
{[2.34]}\end{array}$ & $\begin{array}{l}-3.14 \\
{[8.13]}\end{array}$ & $\begin{array}{c}-19.93 a \\
{[6.58]}\end{array}$ & $\begin{array}{l}-25.28 \mathrm{a} \\
{[2.34]}\end{array}$ \\
\hline Standard Deviation & $\begin{array}{l}6.09 a \\
{[0.79]}\end{array}$ & $\begin{array}{l}4.24 a \\
{[0.57]}\end{array}$ & $\begin{array}{l}3.41 a \\
{[0.17]}\end{array}$ & $\begin{array}{l}7.13 a \\
{[0.63]}\end{array}$ & $\begin{array}{l}5.96 a \\
{[0.55]}\end{array}$ & $\begin{array}{l}3.59 a \\
{[0.15]}\end{array}$ & $\begin{array}{l}6.68 a \\
{[0.63]}\end{array}$ & $\begin{array}{l}4.82 a \\
{[0.48]}\end{array}$ & $\begin{array}{l}3.48 a \\
{[0.16]}\end{array}$ & $\begin{array}{l}6.55 a \\
{[0.70]}\end{array}$ & $\begin{array}{l}5.32 a \\
{[0.59]}\end{array}$ & $\begin{array}{l}3.51 a \\
{[0.16]}\end{array}$ \\
\hline $\begin{array}{l}\Sigma(1,1) \\
\Sigma(2,1)\end{array}$ & & & & & $\begin{array}{c}50.84 a \\
{[9.05]}\end{array}$ & & & & & & $\begin{array}{c}42.86 a \\
{[9.15]}\end{array}$ & \\
\hline$\Sigma(3,1)$ & & & & & $\begin{array}{c}5.99 \\
{[6.18]} \\
28.59 a \\
{[8.92]}\end{array}$ & & & & & & $\begin{array}{c}-0.97 \\
{[1.26]} \\
19.24 a\end{array}$ & \\
\hline$\Sigma(2,2)$ & & & & & $\begin{array}{l}18.92] \\
12.88 \mathrm{a} \\
{[1.08]}\end{array}$ & & & & & & $\begin{array}{l}13.03] \\
12.36 a \\
{[1.14]}\end{array}$ & \\
\hline$\Sigma(3,2)$ & & & & & $\begin{array}{c}13.50 \mathrm{a} \\
{[3.15]}\end{array}$ & & & & & & $\begin{array}{l}7.41 \mathrm{a} \\
{[1.20]}\end{array}$ & \\
\hline$\Sigma(3,3)$ & & & & & $\begin{array}{c}35.49 a \\
{[6.52]}\end{array}$ & & & & & & $\begin{array}{c}28.26 \mathrm{a} \\
{[6.28]}\end{array}$ & \\
\hline Time fixed effects & & Yes & & & Yes & & & Yes & & & Yes & \\
\hline Village fixed effects & & No & & & No & & & Yes & & & Yes & \\
\hline Observations & & 43996 & & & 43996 & & & 43996 & & & 43996 & \\
\hline Log Likelihood & & -6382.62 & & & -6226.48 & & & -6265.72 & & & -6202.47 & \\
\hline
\end{tabular}

Log Likelihood

6382.62

$-6226.48$

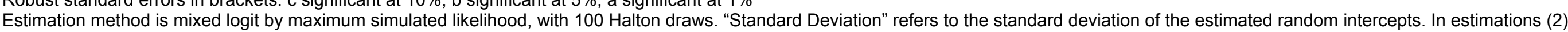
and (4), correlations and heteroscedasticity in the unobservables are allowed, and $\Sigma(.,$.$) indicates the covariance matrix of the correlated random intercepts.$ 